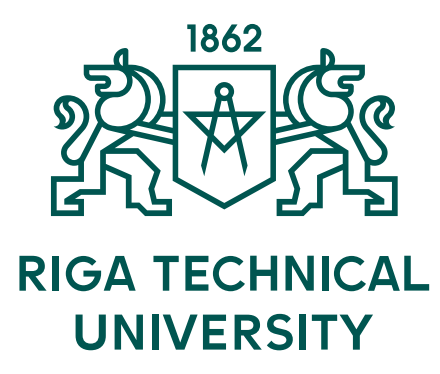

Ilze Miḳelsone

VALUE SYSTEM IN THE ARCHITECTURAL PRACTICE

Summary of the Doctoral Thesis 


\author{
RIGA TECHNICAL UNIVERSITY \\ Faculty of Architecture \\ Department of Architectural Design
}

\author{
Ilze Mikselsone
}

Doctoral Student of of the Study Programme "Architecture"

\title{
Value System in the Architectural Practice
}

Summary of the Doctoral Thesis

Scientific supervisor

Professor Dr. arch.

SANDRA TREIJA

Scientific consultant Professor Dr. habil. arch.

JĀNIS KRASTIN̦Š 
Mikgelsone, I. Value System in the Architectural Practice. Summary of the Doctoral Thesis. Riga: RTU Press, 2019. 70 p.

Published in accordance with the decision of the Promotion Council "RTU P-10" of 27 June 2019, Minutes No. 04030-9.10.1/3. 


\section{DOCTORAL THESIS PROPOSED TO RIGA TECHNICAL UNIVERSITY FOR THE PROMOTION TO THE SCIENTIFIC DEGREE OF DOCTOR OF ARCHITECTURE}

To be granted the scientific degree of Doctor of Architecture, the present Doctoral Thesis has been submitted for the defence at the open meeting of RTU Promotion Council on 30 October 2019, at the Faculty of Architecture of Riga Technical University, 6 Kipsalas Street, Room 433.

OFFICIAL REVIEWERS

Assoc. Professor Dr. arch. Kestutis Zaleckis

Kaunas University of Technology, Lithuania

Professor Dr. arch. Aija Ziemel̦niece

Latvia University of Life Sciences and Technologies, Latvia

Dr. arch. Jānis Zilgalvis

National Administration of Cultural Heritage, Latvia

\section{DECLARATION OF ACADEMIC INTEGRITY}

I hereby declare that the Doctoral Thesis submitted for the review to Riga Technical University for the promotion to the scientific degree of Doctor of Architecture is my own. I confirm that this Doctoral Thesis had not been submitted to any other university for the promotion to a scientific degree.

Ilze Mikselsone (signature)

Date:

The Doctoral Thesis has been written in Latvian. It consists of Introduction; 3 chapters; 9 sub-chapters; Cnclusions; and 8 annexes. The total number of pages is 339 . The bibliography contains 468 titles. 


\section{ANNOTATION}

The aim of the Doctoral Thesis "Value System in Architectural Practice" is to determine the most significant contingent processes and intentional activities that determine value orientation in architectural practice in Latvia based on the analysis of research literature and the findings obtained in the course of empirical research.

The Thesis comprises the introduction, three chapters, conclusions, the list of references, and appendices.

In Chapter 1, "Contributing Factors in Value Orientation of Architectural Practice", the most significant factors driving general changes in the field of architecture in global perspective are considered. It has been identified that many changes occur due to the change of focus in the professional value system, which, in its turn, is determined by value paradigm change in the society as a whole. The most important value contexts of architecture as a service are related to meeting the needs of individuals, and that issue is traditionally solved in the context of market economy, that is, in the context of service provider and service consumer relations. As these relations evolve into the organized processes and the number of participants in these processes keeps growing, interest reconciliation context is becoming more topical. In the context of needs, the changes determined by the value factor ascribed to architectre and architectural practice are analyzed. In the context of market change, the changes driven by the demand factor in architecture and architectural practice are considered. Within the interest reconciliation context, the changes driven by the impact factor in the architectural processes are researched.

Taking into consideration that it is becoming increasingly more apparent that the concept of common value orientation is unfeasible, the author analyzes the basis for formation of the conception of value, and, based on the main principles of axiology, interprets delineation of value orientation formation in the context of architectural practice, highlighting three categories shaping value orientation - architectural concept, architectural result and the regulatory framework for the architectural practice.

In Chapter 2, "Development of Professional Value System in Chronological Perspective", the first and the second value orientation forming categories are analyzed - architectural concept and architectural result. The diversity, nature and scope of application of the architectural value concepts and theoretical framework are studied in a historical perspective. The most distinctive documented conceptions of value, value judgments and manifestations of value orientation in the world and in Latvia are considered in three periods: until the end of the $19^{\text {th }}$ century and at the beginning of the $20^{\text {th }}$ and $21^{\text {st }}$ century, identifying the differences in value criteria design, priorities and trends in communicating values to the general public. 
In Chapter 3, "Formation of Value System in Architectural Practice in Latvia", the third value orientation-forming category in analyzed in detail- regulatory framework for architectural practice. In this chapter, the author assesses interconnection between the architectural values and institutionalized control processes as well as analyzes process performance and its impact on practice. The structure of empirical research presented in sub-chapters illustrates different identified priorities that are initially set as the greatest values within the intuitional framework of each process. The choice of a definite practical process to be analyzed was made based on the research conducted in the theoretical part of the Thesis, results of the survey and expert interviews. It is the authorial interpretation regarding the most typical contexts and the current challenges in the general value orientation in the Latvian architectural practice.

In Sub-chapter 1 of Chapter 3, "Value Orientation in the Cultural Policies of the Industry", functional analysis of the model of dissemination and management of architectural values in the area of culture policies is conducted. In the practical part of research, the specific insight into the ascribed value, demand and contributing factors of this formation type is provided by an in-depth analysis of professional awards. Conclusions on value orientation dissemination trends in industry value promotion and public communication are made.

In Sub-chapter 2 of Chapter 3, "Regulatory Framework for Architecture and Practice", functional analysis of the model of dissemination and management of architectural values in the area of legal regulation of architecture and building processes is conducted. In the practical part of research, the specific insight into the ascribed value, demand and contributing factors of this formation type is provided performing the case study on territory development and planning and by analysis of professional further education programs. The conclusions on the interconnectedness between the planning documents based on the urban development scale value system and market conditions in the development of Mārupe private sector construction are made, and stakeholder issues in professional further education are recognized.

In Sub-chapter 3 of Chapter 3, "Social Integration of the Conception of Value", functional analysis of the model of dissemination and management of practical values in the social process of value reconciliation is conducted. In the practical part of research, the specific insight into the ascribed value, demand and contributing factors is provided by detailed analysis of institutionalized value dissemination in architectural heritage management, architectural sketch competitions and social processes of interest reconciliation. The conclusions on the existing procedures within these processes, actual performance and their impact on architectural practice are made. 
The opinions of practicing architects and industry experts on value orientation trends and the role of management in value system formation in architectural practice have been summarized. Finally, the conclusions made in the course of research on the issues of value dissemination and management, development, transformation and integration, as well as on the impact of the developed practical management instruments on value orientation formation in architectural practice have been systematized. The development tendencies characteristic of the profession of an architect have been determined, and the opportunities to integrate the research findings in further education methods promoting professional advancement of architects have been evaluated.

Development tendencies characteristic of the profession of an architect have been identified and the opportunities to integrate the conclusions made in the course of research within the methods of further architectural education promoting professional advancement have been evaluated.

Research results are reflected in five research papers that have been published in international peer-reviewed scientific publications, three research papers published in professional industry publications and one brochure. The results have been presented at 10 international conferences in Latvia and abroad. 


\section{TABLE OF CONTENTS}

General Description of the Doctoral Thesis …......................................................................... 8

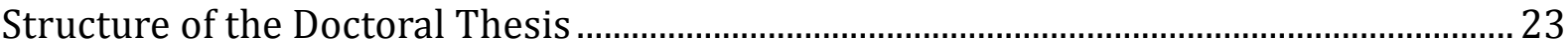

Chapter 1. CONTRIBUTING FACTORS IN VALUE ORIENTATION Of ARCHITECTURAL PRACTICE

Chapter 2. DEVELOPMENT OF PROFESSIONAL VALUE SYSTEM IN CHRONOLOGICAL PERSPECTIVE

Chapter 3. FORMATION OF VALUE SYSTEM IN ARCHITECTURAL PRACTICE IN LATVIA.

Conclusions. 37

List of Sources and Literature 40 


\section{GENERAL DESCRIPTION OF THE DOCTORAL THESIS}

\section{Topicality of the Theme}

Theoretical principles of architecture determine that value criteria interpreted within the cultural, economic and social contexts lie at the origins of architecture. In the human historical experience, architecture has manifested itself as the art of shaping the environment in urban planning and building volumes at various scales, providing a unique reflection of the conception of value. Reflections of the conception of architectural value are being constantly elaborated with illustrations of contemporary architectural value conceptions.

Documenting of the value judgments supplements the illustration of the implemented conception of architectural value. The standard qualities, characteristic of a certain period, that an architectural object is supposed to possess or reach, provide the basis for experience, which becomes the ground for development of the individual and collective understanding of what is worth praise or criticism in architectural objects. At the same time, in line with the global trends, the obtained architectural result ever more frequently illustrates a certain consensus reached by a compromise among the bearers of different conceptions of value. The accents in the formats of assessing architecture are changing, and the focus of attention on selection of the most outstanding architectural objects is being critically analyzed. Similar to the majority of European countries, in Latvia the aim defined in the architectural legislation - the right of every individual to live in a comfortable spatial environment - is not self-obvious, accessible to everyone and widely publicly manifested. At the beginning of 2018, in the internationally recognized Davos Declaration, a general problem of low-quality built environment in Europe was publicly recognized. The link between this problem and the process of architectural development was also recognized, determining it as an important element of Baukultur. An agreement on the strategic meaning of highquality architecture not only in the special status territories but also in the periphery has been reached internationally at the political level.

A support mechanism with purposefully promoted value orientation and independent control is necessary for creation of high-quality built environment. The draft of the Law on Architecture, which started to be considered by the government of the Republic of Latvia in 2010 along with the establishment of a special working group, is just one of the attempts to qualitatively regulate the development of architecture with the entire body of effective normative documents. Since 1991, a number of targeted models for dissemination and management of professional values of that kind have been functioning and developing in Latvia - institutional initiatives and structures that regulate, protect, assess, and control the elements of the architectural value system. 
The issue of low-quality built environment in Latvia is still present not only in the periphery, but often also at the important public objects, consuming inadequate amount of time and financial resources of all stakeholders. In the public setting, the quality of architectural solutions is considered to be the responsibility of the architect, disregarding the obstacle zone that exerts a destructive effect on the architectural intent and result quality. The principles of architectural policy for 2009-2015 mention a range of external problems, considering them the cause of low-quality architecture deforming value orientation of the professional environment and wider public. A loosely defined role of the architect in the construction processes, the resulting critical lack of impact, deficiencies of the regulatory basis, excessive administrative load and other problems have been highlighted. The research on the current state of affairs in the field of architecture conducted in Latvia provides nonflattering statistics regarding the entrepreneurial skills and remuneration.

As a response to the existing situation, the issues pertaining to industry management have come to the fore, and ever more independently on the attempts to control architecture, the attempts to control architectural practice are undertaken. The growing topicality of the architecture evolvement process and the trend for architect's autonomy in the daily activities are reflected in the names of the drafts of the Law on Architecture drawn up in eight years. Initially, it was discussed as the Law on Architectural Quality, later as the Law on Architectural Practice, then as the Law on Architecture and the Law on Environment Quality and Architectural Practice. Taking into consideration the critique of the quality of architecture and architectural services, two approaches are used and developed in the contemporary architectural practice in an attempt to combat the consequences. The first approach is aimed at protection of architectural values and quality assurance, whereas the second approach focuses on the mitigation of problems identified in practice management.

The activities envisioned within both approaches are essentially aimed at the general provision of public rights and promotion of public welfare, and the provider of architectural service - the architect - is the most important target audience for these activities, simultaneously being the receiver of support, a working instrument and a medium. In the current architectural research, the information on the topicalities of daily activities, which characterize significant interconnection between the essential dimensions of profession's value orientation with the environment conditions of the age, has not been systematically summarized. The lack of information on the objective cause of change in value orientation creates the need for a functional audit of composition, dissemination and management of values. 


\section{Current Research on the Theme}

In the research literature, values, understanding of values, attitudes and value orientation are analyzed from different perspectives and in different contexts. This theme is first considered in general, in context of historical world culture events [31], in relation to ethics [123], culture [122], conception of truth [135], [158], cognition and perception [84], development of social paradigms [12], [46], social orders and generational value systems [50], [57], [200]. A large part of research adopts a universal human, cognitive development and philosophical perspective in analyzing basic value-related issues.

In the $20^{\text {th }}$ and $21^{\text {st }}$ century, numerous theories of value categories and their close relation to human needs, perception and context were proposed and developed. Shalom H. Schwartz [252] wrote about the universal structure of values, in the 1950s Abraham Harold Maslow [229] and Max Scheler [128], [251] addressed the issues of value interpretation and needs hierarchy. An original theory of scientific axiology is laid in the studies on value by Robert Schirokauer Hartman and later interpretations of his works [51], [52], [199], [232]. The insights into the range of value research methods are provided in the works of Milton Rokeach [120], [121]. Value perception model developed by Professor of Psychology Clare W. Graves [192] explains the role of perception in value research, it also explains the culture of human interaction. Eugen Bruce Goldstein [331] compiled Encyclopedia of Perception. Integral theory of Ken Wilber [155], [156] and research on world culture values by political analyst Ronald Inglehart [200], [201] analyze value dimensions in regard to the interaction between individual and society, developing and interpreting a map of values [336]. Otto Sharmer, who developed Theory U, analyzed value-related paradigm change in practice management [133], [134]. Sandra Mathison compiled Encyclopedia of Evaluation concerning values in the representational and evaluation contexts [107].

Research on value orientation is often connected with educational system theories, regarding identity issues and integration related challenges in modern society, world view and culture awareness building [138], [279], [280], [344], [235], [236]. Many Latvian authors wrote about the philosophical aspects of the conception of value, for example, Pēteris Zeile [166]-[168], Igors Šuvajevs [262], Maija Kūle and Rihards Kūlis [86]. Professors of the University of Latvia (UL) Skaidrīte Lasmane, Augusts Milts and Andris Rubenis [90], and S. Lasmane [211] wrote about ethics; S. Lasmane and Jurgis Šksilters [212], [260] explored the issues of national identity; Elga Freiberga [189] and Larisa Zeltina [279], [280] studied the Latvian identity in the context of European values.

Cultural aspects considered in the global context widen the perspective of research on universal ethics and the Latvian identity. Peter Burke [8] wrote about cultural diversity, Jonathan Friedman [42] analyzed cultural identity within the global processes, literary scholar Pauls Daija [18] and Dr. art. Deniss Hanovs [197], [198] 
studied cultural transfer and globalization processes in Europe and Latvia.

The principles of sociology may be considered one of the qualitative manifestations of the value context, these principles were analyzed in the works of Martin Albrow [1], Signe Dobelniece [26] and others [353]. Sociological research on values and social customs was conducted by UL professors in social psychology Ivars Austers and Maija Andersone [298], [299], as well as researchers of Riga Stradins University Ritma Rungule and Silva Señkāne [249]. Spodra Austruma [283] developed a voluminous research on values in the consumer society in Latvia within her Doctoral Thesis, Inga Pūre [289] studied the diversity of interests and their reconciliation. Sandra Veinberga [385] wrote about media environment and the role of communication in practical dissemination of value orientation.

With regard to the built environment and architectural values, the research papers are mainly discussed in relation to some definite point of view. A number of authors have been seeking for the answer to questions "what is architecture", "what is the history of architecture" and "where architecture is going" [5], [16], [17], [94], [95], [154], [206], [238], [241]. These questions in general historical perspective are reflected in many anthologies of architecture [2], [37], [38], [110]. Architecture defined as a value and fundamental principles of an autonomous art discipline related to timeless knowledge about aesthetic principles was analyzed in book "Vitruvius on Architecture" [137] by Thomas Gordon Smith, where the author summarized "Ten Books on Architecture" [159] published by a Roman architect Marcus Vitruvius Pollio more than two thousand years ago.

Architectural theories, concepts and basic ideas laid down in manifests that emerged in the $20^{\text {th }}$ century are summarized in the work of architectural theorists Charles Jencks and Karl Kropf [62], as well as other works by Charles Jencks [59]-[61] and in the overviews by Bernard Tschumi [147]. Theoretical principles of regionalism were analyzed by Kenneth Brian Frampton [188] and Henri Lefebvre [97]. Their ideas were supplemented by the theories proposed by Alexander Tzonis and Liane Lefaivre [138]. Vincent B. Canizaro conducted an in-depth research on the theory and practice of regionalism in architecture [13]. Modernity and modernism were theoretically and analytically studied by Albrecht Wellmer [161], K. Frampton [40], K. Frampton and Ashley Simone [41], as well as by Ch. Jencks [59], [60]. The issue of modernism and architecture in Latvia were addressed in the overviews by Jānis Lejnieks [218], [101] and the research developed for the needs of exposition "Unwritten" within 2014 Venice Biennale [222]. A vast body of literature is dedicated to the issue of identity in architecture. Stuart Hall analyzed cultural identity [48], [49], many authors studied identity change in the society [58], [131], [262], Hanss Scotte analyzed identity in modern architecture [253], A. Tzonis and L. Lefaivre - architectural identity in the global environment [96]. In Latvia, identity issues were addressed by architects Eižens Laube [214]-[216], Jānis Krastinš̌ [209], Ivars Strautmanis [140], architectural 
journalist Vladimirs Frolovs [190], and others [326], highlighting various nuances of human search for identity and differences in understanding of the concept of identity in the course of time.

Analyzing the basic values, it is necessary to evaluate the typological standard of architecture developed by the authors of an internationally acknowledged handbook of architecture, German engineers Ernst Neufert and Peter Neufert [113], which was published in 1936 and was revised and supplemented many times. The research literature on the principles of architecture [39], [113], [163], creative process [93], [270], criteria and quality of architecture [182], [269], [276], the issues of criteria incompatibility [271] and architecture assessment [15], [70], [105], [107], [146], [248], [259] is analyzed within the framework of theoretical principles. Aesthetic dimension is investigated in the work by Vladimirs Kincāns "Estētikas pamati" (Foundations of Aesthetics) [64], in the works by Valds Šusts on perception of space and composition [144] and in popular-scientific writing by Umberto Eco on the history of concepts of beauty and ugliness [33], [34].

In the context of value conception, which employs the factor of ascribed value as its prerequisite, any text is so closely connected with a concrete reality that a definite context, working language and author's personality become essential factors in the analysis of descriptions. Considering the architectural result as the final product of cultural, social or commercial values of a group, the literature also addressed the modes of perception, i.e. how authors treat architecture and in what terms one can think about architecture - from the point of view of a philosopher [217], [243], [244], designer [93], emotional aesthete [256], [257], using a complex classification of the range of measures [176], [196], [258], [270] and in other ways. Diversity of value judgments allows including only the most typical ones in the list. Philosophical studies on contextualism, meaning and architectural language in Latvian were published by a philosopher with a degree in architecture Jānis Taurens [145], [263]-[266].

Analyzing the conception of architectural values, many Latvian and foreign authors adopt poetic, emotionally interpretive and tactile materiality approach, which originates in internal emotional experience and individual vision. The work of French philosopher Gaston Bachelard "Poetics of the Space" [4] is still considered one of the most poetic and lyrical documented views on a house. G. Bachelard maintains that the opinions of an individual about houses are shaped by their thoughts, memories and dreams. The aspects of tactile sensations, atmosphere of space and materiality were profoundly discussed by a Finish architect Juhani Pallasmaa [116], [239], in turn, Swiss architect Peter Cumtor wrote about the role of personal, deeply internal resource rooted interpretation in the profession of architect as an elitist trade [17]. In book "Thinking Architecture" [17], P. Cumtor discusses motivation and achievements in architecture as a creative act in which the architectural work originates and goes beyond any historical and technical knowledge. Architect Aldo van Eyck [272] 
emphasized that poetry and human nature are the greatest values in architecture, V. Šusts [261] wrote about houses and comfort.

A totally different approach is adopted in the research on interconnection between understanding of space and external environment - postmodernism, capitalism, globalization, consumerism and neoliberation processes in the society. At the turn of the $20^{\text {th }}$ and $21^{\text {st }}$ century such issues as the role of the conception of space in theoretical research and different interpretations of the notion of space within different conceptions gained momentum in the scientific discussion [150], [151]. The growing complexity of decoding the conception of value is attested in the works of Martin Albrow [1], Robert Hollinger [55], Nigel Watson [160], Ronald Inglehart [57], [200]-[203], Maximilian Weber [152], Steven Miles [111] and Roger Keil [207], where a social and cultural geography approach has been developed taking into consideration the "spatial turn" taken by the social and cultural theory. Editor Mike Crang in hisbook "Thinking Space" [16] also summarized a large number of works by social theorists, where complicated and differentiated geographical notions and metaphors are used to describe the world.

The issue of architectural values is addressed in the works of local classics, Professors Eižens Laube [214]-[216], Pauls Kundziņš [82], and Ivars Strautmanis [139]-[141]. "Theoretical Papers and Manifests of the Latvian Architects in the 20 Century" [104] complied by Jānis Lejnieks and Zanda Redberga is the most significant source of evidence on the conception of value in the Latvian architecture. The book provides a summary of important, specific opinions of the historical period of such architects as Eižens Laube (1908, 1930, 1934), Pēteris Bērzkalns (1930, 1938), Ivars Strautmanis (1973), "MĀJA Group" (1991), Ēriks Fogels (1970), Jānis Krastin,š (1983) and Valdis Šusts (1990) about the architectural language, national and regional identity, the relationship between the old and the new. The view of the environment where Latvian architecture evolved is studied also in other research papers by academicians in architecture Jānis Krastinšs, Ivars Strautmanis, and Jānis Dripe [78], [79]. Literary historian Pauls Daija studied value formation as constructed reality in the context of cultural transfer, particularly with respect to the role and contribution of the Baltic Germans to the early Latvian literature and culture in general [18]. This issue was also analyzed in the joint work by Prof. Jānis Krastiṇš and Prof. Ojārs Spārītis on Riga architecture mirroring the European culture during eight hundred years [75], and in their joint work with Imants Lancmanis on German architects in Latvia [76].

"Latvieša māja" (Latvian House) published in 2014 is one of the most comprehensive modern studies on the Latvian lifestyle in relation to housing with regard to the origins and reflection of the local value conception tradition in the Latvian built environment; it covers the period from the $13^{\text {th }}$ century up to present [83]. Folklorist, historian and ethnographer Janīna Kursīte in her research on values analyzed the views on the Latvian house in six longer historical periods. The scholar 
stressed that erecting a house, maintaining the house and its surroundings are an element of human identity that characterizes a person both as an individual and as a member of a group - family, social class, nation to which a person belongs. In her book, she pays tribute to the opinions of ethnographers, architects and historians and thoroughly investigates national housebuilding, not only as the physical activity and practice of putting building elements together, but also as the act of creation of the world, assessing it through the prism of folklore, mythology and symbolism. An important statement on the situational values in various periods of the Latvian history is made in collective monograph "Latvijas architektūra no senatnes līdz mūsdienām" (Latvian Architecture from Ancient Times until Present) [79]. Jānis Lejnieks studied the views of his generation on architectural practice in Latvia in the $20^{\text {th }}$ century starting with the post-WWII period until the turn of the $21^{\text {st }}$ century in monograph "Patiesa forma. Tīrs stils. Modris G Gelzis. Arhitekts.” (True Form. Pure Style. Modris Gelzis. Architect) [101]. Value judgments, attitudes and orientation typical of the time are discussed in many other books by J. Lejnieks [98]-[104].

In the last 20 years, the descriptions of built environment and the most characteristic seminal architectural objects of the time demonstrating the values of our country were published in voluminous publications [54], [68] and periodicals. Descriptions in the documents on annual architectural awards, competitions and their selection criteria, as well as the selection in the Latvian Culture Canon [348], can be added to this corpus. In the area of research on the architectural cultural-historical heritage historian Mārtiňš Mintaurs conducted an in-depth research taking into consideration public and state attitudes and the aspects of cultural politics in different periods [112]. Important documents on heritage were also summarized by other researchers [205], [291] and the representatives of the National Cultural Heritage Board [119], specifically by the Head of the Board, architect Juris Dambis [19], [20].

The issues and topicalities pertaining to architectural practice and conception of value in relation to architectural processes in Latvia were documented in a number of contemporary publications by architects-publicists Vents Vīnbergs, Ieva Zībārte and others [157], [169]-[171], [190], [194], [222], [386]-[388]. A few surveys published on the issue may be considered another source for research on modern value orientation, for example, a public opinion poll "What is good architecture?" conducted by architectural bureau "Sarma un Norde" in 2006 in three target groups [391], an annual voluntary questionnaire for architects run at architectural portal "a $4 \mathrm{~d}$ " concerning the most significant events of the year [296], and the survey conducted by the Latvia Association of Architects in 2013 on the status of the profession of an architect in the country and the setting of operational priorities [346].

In the history of architectural theory, the issues concerning the praiseworthy or reprehensible matters happening with the architectural object are widely and actively discussed, whereas the challenges associated with these objects are largely 
disregarded. Since the turn of the $21^{\text {st }}$ century, more and more studies dedicated to the issues related to architectural practice appeared, a range of studies has also addressed the environment where architecture evolves. Management of architectural processes or "architecture of architecture" has been the focus of interest of many architecture scholars.

Practice is analyzed as an inherent element of architect's profession [142], [149], [273], [274], as a platform of process management and competition [25], [65], [68], [115], [220], and as a range of practical issues related to various condition induced changes. David Oakley wrote about radically different value orientation conditions in the process of architecture evolvement in view of cultures in change [114]. Hossein Sadri wrote about respecting human rights in spatial environment and about the impact these principles have on both the environment and professional practice [125].

In many literary sources on the architectural practice processes, special attention is paid to the aspect of stakeholder cooperation. The growing impact the public has on architecture is particularly widely analyzed in the research literature with regard to the civil society and planning, mainly considering the power factor rather than the consequences or the obtained result [63], [204], [233]. In the research on architecture evolvement processes, scholars mention the growing demand for interaction, communication and marketing skills [53], [73], [153], discuss varying perspectives in the architectural processes [91], [182], [183], [245], [276]-[277] and make references to the related research on public rights provision and control [127], [219], [221], [234], [328], [368]. The book by British geographers Rob Imrie and Emma Street "Architecture Design and Regulation" [56] is an important source promoting understanding of the interests of growing stakeholder groups and normative paradigm.

Realization of cooperation inevitably influences the forms of impact. Previously, the research specifically on the chronological changes in the contributing factors in architectural processes has not been performed, however, many authors showed profound interest in the issue. Robert Greene in his book "48 Laws of Power" [45] provides a comprehensive overview of a thousand-year long history of power. The relationship between ideology and architecture has been addressed by many researchers [106], [340], these issues were also discussed at international conference "Architecture \& Ideology" [228] in Belgrade in 2008. Albena Yaneva [164], [165] analyzed power and control as a complex problem of the contemporary architecture. A. Yaneva mapped the controversies in the development of significant architectural objects, developed an actor-network approach methodology and established a special study program for architecture students at the University of Manchester [278].

Architectural practice development strategies were captivatingly analyzed by Prof. Eduard Sancho Pou in his work "Function follows strategy. Architects' Strategies from the Fifties to the Present" [126]. He investigated how marketing, politics and social data influence architectural design and design process. Professor of Yale University Peggy Deamer in ok "Architecture and Capitalism: 1845 to the Present" [22] 
comprehensively analyzed economic process related challenges in architecture. The author summarized architectural experience in dealing with economic situation induced challenges in different periods and in different countries, as well as analyzed the relationship between economics and architectural design.

"Neo-Liberalism and the Architecture of the Post Professional Era" published in 2018 presenting the summary of international research compiled by an editor H. Sadri [124] provides insights into great changes in the value accents of the architectural design practice. The work highlights the impact of neoliberal policies and real estate market on the architectural and urban development practice. It is maintained that at present practice is experiencing transition from the age of "professionalism" to the age of "post-professionalism". The collection of essays published in 2015, "The Architect as Worker: Immaterial Labor, the Creative Class, and the Politics of Design" [21], offers insights into daily architectural activities, trying to establish the connection and interrelation between the work of an architect, value and creative pleasure, reflecting on the contemporary foundations of architecture. The work addresses the following vital issues of architectural practice: architectural practice theories and the essence of design, categorization of immaterial and creative work, the link of professional labor force with the requirements of BIM (Building Information Modeling) approach, architectural entrepreneurship, architectural practice ethics and remuneration opportunities.

The necessity to implement systemic and curriculum-related reforms of the education system to respond to the most typical global challenges of the $21^{\text {st }}$ century was substantiated by Charles Fadel, Maya Bialik, Bernie Trilling, the researchers of the Center for Curriculum Redesign, in their extensive study "Four-Dimensional Education" [36]. Transformation of professional education was studied by Lori Brown [180], the challenges related to the skills developed at the university and the requirements of the labor market were considered by Barbara Golter Heller [334] and other authors [143], [181]. The stages of professional education development and the main reference points in Latvia were analyzed in "The Oldest University in the Baltics - Ages and Personalities" [132]. The structural framework of professional further education is defined in the regulations of the Architect's Council of Europe [400]. Since 2007, many comprehensive professional research papers were published on the initiative of the Ministry of Culture of the Republic of Latvia dedicated to the aspects of industry practice, summarizing and analyzing statistical data in many categories [175], [186], [220], [275]. The main conclusions made in the recent industry reviews attest that presently there is a close connection between the unsatisfactory quality of architecture and trends of architectural practice.

The existing research on the theme includes a vast body of literature and studies on the conception of value, where the phenomenon of architecture is seen as a set of elements with changing priorities in knowledge, skills and communication dimensions. 
In the research on architectural practice environment in Latvia in the $21^{\text {st }}$ century, the circumstances under which the main values of architecture lose their position as priorities in architectural practice have been identified but have not been sufficiently researched. The prerequisites of value orientation change, which emerge in the course of interaction between the main professional value principles of architecture and the circumstances where they evolve, have not been previously assessed. That actualizes the need to evaluate the circumstances having an impact on the work of an architect and intended prerequisites in the historical and modern contexts. The topicality of the problem determined the choice of the theme, research object and research aim of the Doctoral Thesis.

The object of the research is value system in architectural practice in the context of formation of value orientation.

The aim of the research is to determine the most significant contingent processes and intentional activities that determine value orientation in architectural practice in Latvia.

\section{The tasks to achieve the aims are as follows:}

- to consider theoretical framework in the research literature on value analysis methodology, the main value sub-systems forming architectural practice and the factors contributing to value orientation in e architectural practice;

- to summarize manifestations of the main factors contributing to value orientation in the built environment and architectural practice in chronological order;

- to organize individual, in-depth and semi-structured expert interviews with architectural practitioners from senior generations on the circumstances forming value orientation in different periods;

- to compare information on the most important circumstances that have influenced the professional value system in global and local perspective since 1991;

- to determine the main forms of intentional value orientation in architectural practice in Latvia and evaluate the disciplinary measures developed to achieve the aims set in the architectural practice related to these forms;

- to conduct functional analysis of the models of dissemination and management of definite characteristic typological values within architectural practice for the period from 1991 to 2017, obtaining compatible results for determining interconnection between the contributing factors of value orientation, formation of value orientation and professional qualification advancement;

- to poll practicing architects in order to discover their opinions on the priorities in value orientation in the modern architectural practice and on the most significant obstacles in the approbation of value criteria;

- to poll practicing architects in order to discover their opinions on the impact of administrative and social processes on practice in the context of reconciliation of stakeholder interests; 
- to draw conclusions on interconnection between the intentional formation of value orientation and the factors contributing to value orientation in modern architectural practice;

- using the data obtained within the research "Opportunities for Improvement of Professional Further Education Program", to integrate and synthesize the gained results in the conclusions on future professional further education development opportunities.

\section{Research Methods}

The theoretical framework of the Doctoral Thesis is formed by the research literature, articles, publications and documents published in different countries, including the EU countries and Latvia, as well as Internet resources. Based on the theoretical analysis of research literature and adopting the systems analytics approach, an empirical research is conducted, using the following research methods:

- comparative analysis is used for:

- analysis of literature on the application of value research methods;

- analysis of the data on the history of development of value orientation and its contributing factors;

- analysis of strategic industry documents, regulatory legislative enactments and documents within the institutionalized value orientation systems - in the segment of awards, urban development and planning, architectural heritage management, competitions and within interest reconciliation procedures;

- analysis of survey results;

- visual comparative analysis is used to determine the factors contributing to environment identity in field inspection of the housing development in Riga District;

- secondary analysis of the previous research data is used in the research of the given research theme;

- Phronetic Planning Research proposed by Bent Flyvbjerg is used to concurrently consider theoretical arguments, methodological guidelines and the cases of practical application;

- a survey of architects practicing in Latvia on professional further education (297 respondents, of which 241 chartered architects);

- a survey of architects practicing in Latvia on the topicalities of their practice and value orientation (177 respondents);

- a survey of experts through individual, in-depth and semi-structured interviews (sample of 14 respondents);

- a survey of architects practicing in Latvia on the reconciliation of stakeholder interests (40 respondents); 
- graphic and analytical processing and interpretation of results and data obtained in the course of research.

The terms applied in the Doctoral Thesis are used in their established sense, using various reference sources as the basis for definition, in some cases supplementing their conceptual content with interpretations relevant in the context of the present Thesis. The terms in the Thesis are used in the following sense.

Architectural practice - activities in the field of architecture, including education, research, creative processes, design, administration and management. Within the Thesis, the term "architectural practice" denotes architectural ideas, the total of result and evolvement conditions and modern conceptions of value related thereto, value criteria and the regulatory framework for the architectural practice.

Value system - conditionally analyzed body of society-related value aspects and profession-related value categories that determine diverse prerequisites of architectural evolvement.

Value aspects - criteria of value system research, within this Thesis, the terms "conception of value" and "value orientation" are used. Value orientation - a deliberation or action aimed at a definite purpose, the focus of a certain activity on definite values as priority. Conception of value - the state, in which the essence, content, meaning of some aspect of architecture or professional practice is perceived and understood in a definite way.

Categories forming value orientation - the total of ideas, criteria and regulatory enactments that a person or a group of people have tried to consistently realize and implement in their activities with an aim to reach a definite result in architectural practice. Within the meaning of the Thesis, categories forming value orientation include architectural idea, architectural result and the regulatory framework for architectural practice. Architectural concept - conceptual framework of values that is seen as a gold standard of qualities an architectural object is supposed to reach. Within the meaning of the Thesis, these are manifestation of concepts, judgments, ideas, manifests that reflect the rationale of architectural activities performed in a certain period of time. Regulatory framework for the architectural practice - obligatory or conventional course of measures and activities implemented in the architectural practice in order to establish, promote or protect definite architectural object related values. Architectural result - an architectural object developed within a set of definite value criteria.

Value orientation forming processes - external circumstance induced prerequisites, which may potentially change the accents of professional value orientation in architectural practice in terms of degree of their importance.

Formation of value orientation - the way how activity(ies) are purposefully organized in the current architectural practice in order to influence value orientation 
in a definite direction (cultural policies, legal regulatory framework for architecture and practice, value reconciliation within administrative and social processes).

\section{Scientific novelty of the Doctoral Thesis}

The Doctoral Thesis presents a theoretical generalization on the issues of value conception, attitudes and orientation in the architectural practice and identification of regularities in contingent and intentional formation of value orientation. The data summarized in the Thesis have not been previously collected and analyzed in their totality. The research results include conclusions on the current trends in value orientation in the Latvian architectural practice.

\section{Practical significance of the Doctoral Thesis}

The results obtained in the Thesis and the data base developed in the course of research present a scientifically validated source of reference on the value conception based architectural practice, which may be useful for any architectural student, practicing architect or any other interested party. The developed Thesis presents a theoretical and methodological basis that allows developing recommendations on the curriculum and action plan for professional further education.

\section{Approbation of research results}

The course of research and its results have been reported at a number of international and local scientific conferences, as well as published in scientific journals, collections of research papers and industry publications.

\section{Publications}

1. Mikselsone, I. Custom-Made Patchwork Landscape: Entrepreneurial and Private Regionalism. Science - Future of Lithuania = Mokslas - Lietuvos Ateitis, 2014, Vol. 6, No. 3, pp. 290-302. ISSN 2029-2341. e-ISSN 2029-2252. Available at: doi:10.3846/mla.2014.41.

2. Mikelsone, I., Treija, S. Quantitative and Qualitative Parameters of Awards in Architecture and Construction Industries of Latvia. Science - Future of Lithuania = Mokslas - Lietuvos Ateitis, 2015, Vol. 7, No. 1, pp. 89-100. ISSN 2029-2341. e-ISSN 2029-2252. Available at: doi:10.3846/mla.2015.724.

3. Mikselsone, I. Architectural Competitions as an Instrument for Heritage Protection: the Dynamics of Competition Taxonomy. Journal of Architecture and Urbanism, 
2016, Vol. 40, No. 4, pp. 272-282. ISSN 2029-7955. e-ISSN 2029-7947. Available at: doi:10.3846/20297955.2016.1246985.

4. Mikselsone, I. Methodology in Attitudes Assigned to Architecture as Distinctly Regional. Architecture and Urban Planning, 2016, No. 11, 2016, pp. 43-48. ISSN 1691-4333. e-ISSN 2255-8764. Available at: doi:10.1515/aup-2016-0006.

5. Mikselsone, I. Apbalvojumu eklektika arhitektūras un būvniecības nozarē Latvijā. Latvijas Būvniecība, 2015, Nr. 3, 2.-7. lpp. ISSN 1691-4058.

6. Miḳelsone, I., G̦elzis, K. Padomju okupācijas upuru memoriāls. Latvijas Arhitektūra, 2015, Nr. 119, 74.-75. lpp. ISSN 1407-4923.

7. Mikelsone, I. The Role of Social Engagement in the Development of Significant Architectural Objects. Architecture and Urban Planning, 2017, No. 13, pp. 6-14. ISSN 1691-4333. e-ISSN 2255-8764. Available at: doi:10.1515/aup-2017-0001.

8. Miḳelsone, I. Būvprojektu ekspertīze un tās izaicinājumi. Latvijas Būvniecība, 2017. Available at: www.buvniekupadome.lv/likumdosana.

9. Mikselsone, I. (ed.) Latvijas arhitektūras politika 2020. Riga, 2019. 72 lpp. ISBN 9789934198298.

\section{Reports at conferences}

1. Mikselsone, I. Tradition Versus Modernity in Regional Architecture. Riga Technical University 54th International Scientific Conference, Latvia, Riga, 16 October 2013.

2. Mikselsone, I. Methodological Pluralism in Regionalism Research. Riga Technical University 55th International Scientific Conference, Latvia, Riga, 14-15 October 2014.

3. Mikelsone, I. Custom-Made Patchwork Landscape: Entrepreneurial and Private Regionalism. Science - Future of Lithuania = Mokslas - Lietuvos Ateitis, Lithuania, Vilnius, 14-15 February 2014.

4. Mikselsone, I. Architecture 'Actors' by Actor-Network Theory (ANT) Approach. Riga Technical University 56th International Scientific Conference, Latvia, Riga, 14-15 October 2015. 
5. Mikselsone, I. Quantitative and Qualitative Parameters of Awards in Architecture and Construction Industries of Latvia. In: Science - Future of Lithuania = Mokslas Lietuvos Ateitis, Seselgis, Lithuania, Vilnius, 14-15 February 2015.

6. Mikselsone, I. Vērtīguma hierarhija Rīgas Vēsturiskajā centrā. Strēlnieku laukuma piemērs, R. Šmēlinga konference, Latvia, Riga, 29 October 2015.

7. Mikselsone, I. Regional Features of Public Discussion in Architecture. Riga Technical University 57th International Scientific Conference Book, Latvia, Riga, 13 October 2016.

8. Mikselsone, I. Selling of Design: Evolving Typology of Architectural Strategies in Latvia. Riga Technical University 58th International Scientific Conference Book, Latvia, Riga, 14 October 2017.

9. Mikselsone, I. The Study on Value Hierarchy in Architecture. Riga Technical University 58th International Scientific Conference Book, Latvia, Riga, 12 October 2017.

10. Miķelsone, I. Arhitektūras profesionālās tālākizglītības programma un tās pilnveides iespējas. Latvijas Arhitektu savienības 21. kongress, Latvija, Riga, 20 April 2018.

The Doctoral Thesis consists of the introduction, three chapters and conclusions, the list of references including 468 entries in the Latvian and English language.

In order to illustrate the textual data, figures from personal archive of the author of the Thesis and other sources are used. The figures that do not have a source reference in the legend are created by the author of the Thesis. 


\section{STRUCTURE OF THE DOCTORAL THESIS}

\section{INTRODUCTION}

\section{Contributing Factors in Architectural Practice Value Orientation}

1.1. Factor of Ascribed Value in the Context of Needs

1.2. Demand Factor in the Context of Market Change

1.3. Impact Factor in the Context of Interest Reconciliation

\section{Development of Professional Value System in Chronological Perspective}

2.1. Formation of Value Orientation until the End of the $19^{\text {th }}$ Century

2.2. Development of Value Orientation in the $20^{\text {th }}$ Century

2.3. Dissemination of Value Orientation in the $21^{\text {st }}$ Century

\section{Formation of Value System in the Architectural Practice in Latvia}

3.1. Value Orientation in the Cultural Policies of the Industry

3.2. Regulatory Framework for Architecture and Practice

3.2.1. Regulatory Enactments in Development of New Territories

3.2.2. Professional Further Education Program

3.3. Social Integration of the Conception of Value

3.3.1. Architectural Heritage Management

3.3.2. Architectural Competition Practices

3.3.3. Public Hearing Procedures

\section{CONCLUSIONS}

\section{LIST OF SOURCES AND LITERATURE}

\section{APPENDICES}

Appendix 1. Information about the research “Opportunities for Improvement of Professional Further Education Program"

Appendix 2. Questionnaire for Architects "Value Orientation of an Architect's Practice" Appendix 3. Survey Results

Appendix 4. Expert Interview Questions

Appendix 5. Interviewed Experts

Appendix 6. Summary of Expert Interview Results

Appendix 7. Questionnaire for Architects "Reconciliation of Stakeholder Interests in the Latvian Architectural Practice"

Appendix 8. Survey Results 


\section{CHAPTER 1. CONTRIBUTING FACTORS IN VALUE ORIENTATION OF ARCHITECTURAL PRACTICE}

Chapter 1 "Contributing Factors in Value Orientation of Architectural Practice" is mainly dedicated to categorization of the factors contributing to value orientation in the contexts related to architectural practice. The most significant challenges and the main factors that cause the general shift in value orientation accents in the field of architecture and the built environment on the global scale are considered.

Formation of value orientation in the built environment is influenced by a great number of factors, however, ascribed value, demand and impact are three main factors. Summarizing information on the most significant factors contributing to architectural practice - ascribed value, demand and impact - it has been discovered that all three factors may be analyzed only in the context of definite value conceptions. The concept of values is one of the oldest questions humanity tried to reflect on, and from scientific point of view, axiology or the study of value is the most comprehensive framework for analyzing values, where the subjects of value are classified into ideas, things and people (Fig. 1.1).

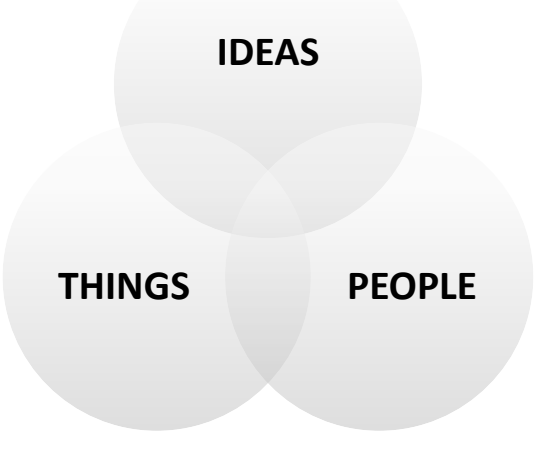

Fig. 1.1. Main principles of axiology in the analysis of factors contributing to value orientation.

It has been concluded that the categories studied and classified by axiology are manifested and lose their neutrality in the attitudes developed under the impact of the emotional states of an individual, socio-economic experience and definite traditions. All three factors (Fig. 1.2) - independently or in interaction - may influence value orientation in relation to:

- ideas that exist in architectural practice;

- things that exist in architectural practice;

- people who deal with architectural practice. 
Architectural idea

FACTOR OF ASCRIBED VALUE

\section{Architectural result \\ DEMAND FACTOR}

Regulatory framework for architectural practice

IMPACT FACTOR

Fig. 1.2. Interpretation of interaction among value categories based on the main principles of axiology in the analysis of factors contributing to value orientation in architectural practice.

Sub-chapter 1 of Chapter 1 assesses the factor of ascribed value in the context of needs. The author analyzes the structure of value basis and summarizes information on the conditions upon which the ascribed value forms ideas about values. Based on the main principles of axiology, the author interprets the delineation related to the architectural practice context for analysis of value orientation formation and defines three categories: architectural idea, architectural result and regulatory framework for the architectural practice. It has been concluded that the factor of ascribed value in various aspects generally characterizes the person's ability to perceive and understand definite value factors differently, ascribing them different priority. The conception of value is the ideas about the types and meaning of value in the value system of a concrete individual or social group, it may differ depending on the historical development stage of a socio-political system and its specifics. The criterion of meaning forms the basis of value, which can be considered only comparatively.

Sub-chapter 2 of Chapter 1 evaluates the demand factor in the context of market change. The author summarizes information on the global phenomenon of consumerism and consumer society, which, on the one hand, provides the opportunity to choose, but on the other hand, imposes values. It has been concluded that the demand factor with regard to value orientation is mainly related to the result obtained in the course of architectural practice. In the context of market economy and consumer society, architecture is becoming a commodity and design practice is connected with service provision under competition. 
Sub-chapter 3 of Chapter 1 analyzes the impact factor in the context of interest reconciliation. It has been concluded that the impact factor is actualized in the environment formed by many factors, many opinions, and different views. The needs that lie at the basis of values have not changed in the course of history, but the ways in which these needs are satisfied have. The relationships that exist in the modern architectural practice get progressively transformed into organized processes, and the need to assess opinions and simultaneously process them emerges regarding the service element of architecture. Considering practice in general, especially in conditions of market economy induced scarcity of resources, the idea of interest reconciliation logically leads to the question about rights and opportunities to represent one's values, about planned and strategic approach to meeting some interests, about forms of impact and hierarchy of impact, as well as the influence of the impact factor on value orientation in architectural practice in general. 


\section{CHAPTER 2. DEVELOPMENT OF PROFESSIONAL VALUE SYSTEM IN CHRONOLOGICAL PERSPECTIVE}

Chapter 2 is structured chronologically. In this chapter, it is analyzed how value communication has changed in the course of time using architecture as a medium. The idea of architecture's worth is analyzed as a category of value orientation formation in the historical perspective, considering the diversity, nature and dissemination channels of the concept, criteria and theoretical principle of the architectural values.

The author summarizes the typical documented conceptions of value, value attitudes, and manifestations of value orientation before the $20^{\text {th }}$ century, in the $20^{\text {th }}$ century and at the beginning of the $21^{\text {st }}$ century in Latvia and in the world, identifying the differences in the composition of value criteria, priorities and tendencies in explaining values to the public. The tendencies in division of value dissemination between architectural value management and practice value management have been identified.

In Sub-chapter 1 of Chapter $\mathbf{2}$ the main prerequisites of value orientation formation until the end of the $19^{\text {th }}$ century are considered.

In Sub-chapter 2 of Chapter 2 the diversity of value attachment and the main architectural theories of the $20^{\text {th }}$ century are considered.

In Sub-chapter 3 of Chapter 2 the modern contribution at the turn of the $21^{\text {st }}$ century is determined, the most significant evidence and publicly approved value related documents are analyzed. The most widely known types of manifests of architectural values and their current applications have been identified (Fig. 2.1).
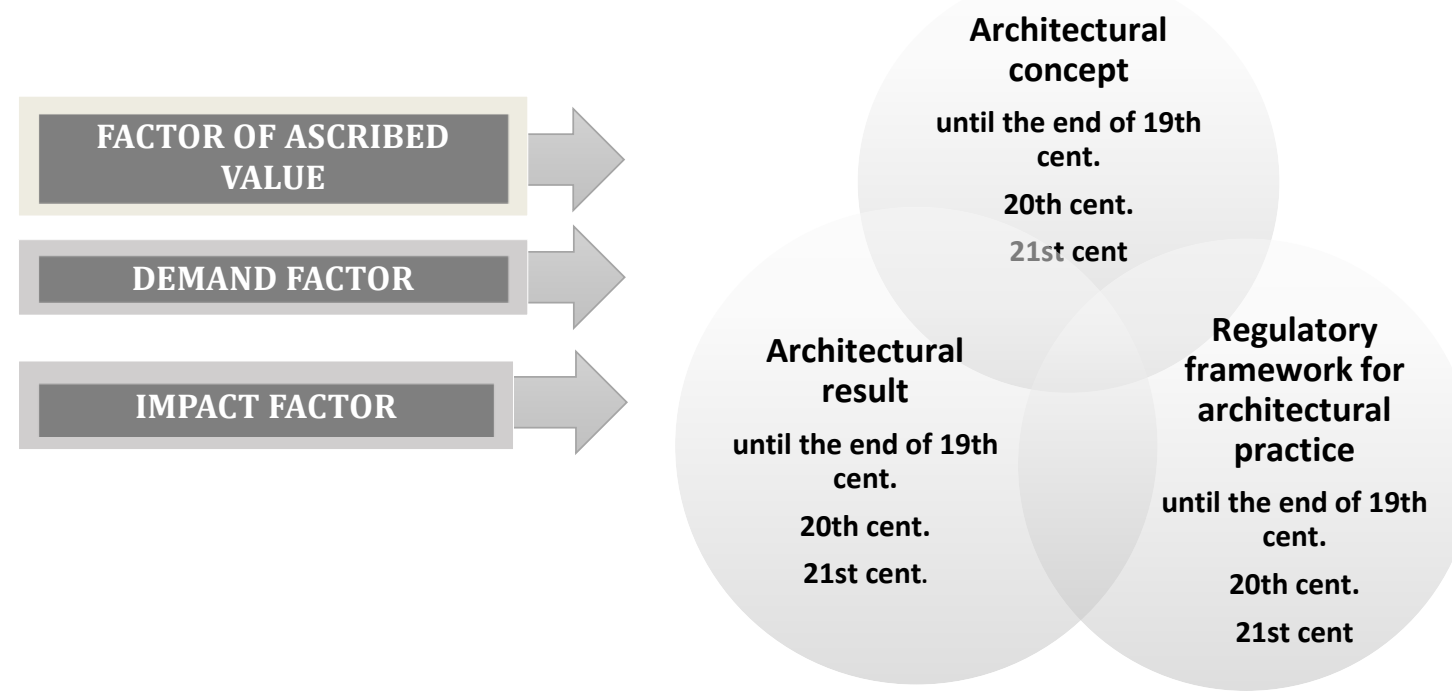

Fig. 2.1. Analysis of the factors contributing to value orientation in the categories of value orientation until the end of the $19^{\text {th }}$ century, in the $20^{\text {th }}$ century and $21^{\text {st }}$ century. 
Value conception heritage is passed over to the next generations in a variety of ways: as ideas, buildings, and as empirical knowledge, competences and skills. Each period is characterized by distinct people and events that contributed to formation of the main value principles of the architectural and professional practice, traditions and the most characteristic viewpoints. In the course of research, it has been observed that in the chronological perspective value orientation in architectural practice until the end of the $19^{\text {th }}$ century, in the $20^{\text {th }}$ century and $21^{\text {st }}$ century was manifested differently. The main differences have been identified in value recognition and criteria accents. The modes of interaction between the commissioner, the architect and the wider public also differ, as well as their views shaping architecture and practice.

In all periods, the ascribed value or the ideology dominating in architecture is closely related to the needs, opportunities and conceptions regarding real estate development and its meaning within the value system of a definite individual or social group. In the history of European architecture, a large corpus of arguments concerning the ascribed value has been collected. The factors of ascribing meaning in real estate development by the end of the $1^{\text {th }}$ century were mainly influenced by the way of life typical of a certain age, types of employment, interests of powers and superpowers, and territorial rearrangement. Architecture is characterized by stylistic diversity. The dominating ideas of the $\mathbf{2 0}^{\text {th }}$ century architecture were influenced by various attempts to explicate architecture intellectually and conceptually and by emergence of different movements. In essence, it is theoretical, emotional, poetic or ideological nature of values that is exposed through architecture. Fundamentally rationalizing architecture, modernism embodies a new value orientation paradigm. The need to recognize the phenomenon of origin and belonging is brought about by the National Romanticism, regionalism and contextualism. Value orientation in architecture in this period also became the object of academic analysis, as a result, classifications and theoretical principles for creation of synthesized spatial forms were developed. The ideological environment of architecture and practice of the $21^{\text {st }}$ century is characterized by eclectism of historical ideas about value orientation with a distinct ethical dimension in its broadest sense, including such ideas as sustainable development, cultural responsibility for heritage, civic awareness, cognitive community, tolerance for diversity and other ideas. Complex assessment systems of stylistic diversity of the housing development in the conditions of tolerance do not comprise the humanistic ideals and aesthetic spatial parameters. Value orientation focuses on the practical aims that should be reached through architecture rather than otherwise. Certain differences are identified regarding value ideals and concepts, approaches, nature and ways of dissemination of values. For example, such broad non-measurable value concepts as identity, image, the concept of architectural character, compatibility of the massing with the environment, context, sustainability and other concepts are still influenced by their wide application and interpretation, however, they are increasingly actualized anew within the 
argumentation formulas beneficial for a definite occasion.

Most frequently, the demand factor in the built environment is closely connected with the historical circumstances. Until the end of the $19^{\text {th }}$ century, the matters of survival and need for protection were the most urgent issues. Within the value orientation system of the elite, architecture was mainly seen as a symbol of welfare and status, significance was ascribed to the aesthetic dimension of architectural styles and the quality of civil engineering performance. In the $20^{\text {th }}$ century, demand factor accents were mainly determined by population growth and the consequences of two world wars, as well as the development of typology regarding growing demands towards household conveniences, education, healthcare, and other areas. The demand for independence from classic aesthetics in architecture was growing. Value orientation was influenced by engineering innovations and fundamental changes in materiality; concrete, glass, and metal became the most popular building materials. The demand under Soviet occupation regime was subject to various restrictions. In the $21^{\text {st }}$ century, the demand factor in the development of the built environment is subject to a significant influence of consumer society value orientation, pluralism, and rapidly changing and unpredictable circumstances. The demand that determines the requirements towards architecture is gradually supplemented with the demand that determines the requirements towards architectural practice and the architect.

The impact factor in the built environment is connected with power relations and the tools maintaining them. Until the end of the 19th century, the commissioner had the largest influence on value orientation in the built environment - a wealthy and influential person, who authoritatively commissioned the building. Architecture was created by well-educated personalities - architectural experts. City plans were developed by experienced military engineers, whereas foremen and craftsmen were responsible for construction. In the territory of Latvia, the origins of professional education and practice started to evolve at the end of the 19th century, German and Baltic German cultural environment considerably contributed to this process. The largest impact on architecture in the $\mathbf{2 0}^{\text {th }}$ century was associated with embodiment of a definite architect's architectural concepts, manifests were considered a peculiar from of impact. Architecture evolved in conditions of the dominating trends and totalitarian socio-political system, under the impact of various normative and technological restrictions. In the $21^{\text {st }}$ century, architecture is evolving in difficult political, economic, and social conditions and cultural dialogue, the number of value orientation related challenges is growing with regard to both the quality of architecture and that of architectural practice. Value orientation is influenced by both progressive architecture explicitation applications and industry and practice management aspects. It is observed that the topicality of three value categories considered - ideas, buildings, and regulatory framework - has not changed, still, purposeful value orientation formation system for all these categories has developed both qualitatively and quantitatively. 


\section{CHAPTER 3. FORMATION OF VALUE SYSTEM IN ARCHITECTURAL PRACTICE IN LATVIA}

In Chapter 3 the author evaluates the interaction between architectural value and processes of institutionalized control, analyzes process performance and its impact on practice. To analyze the aims set in the Doctoral Thesis, the procedures functioning in the modern practice that aim at influencing professional and public value orientation towards environment quality promotion are analyzed within the applied practice processes (Fig. 3.1).

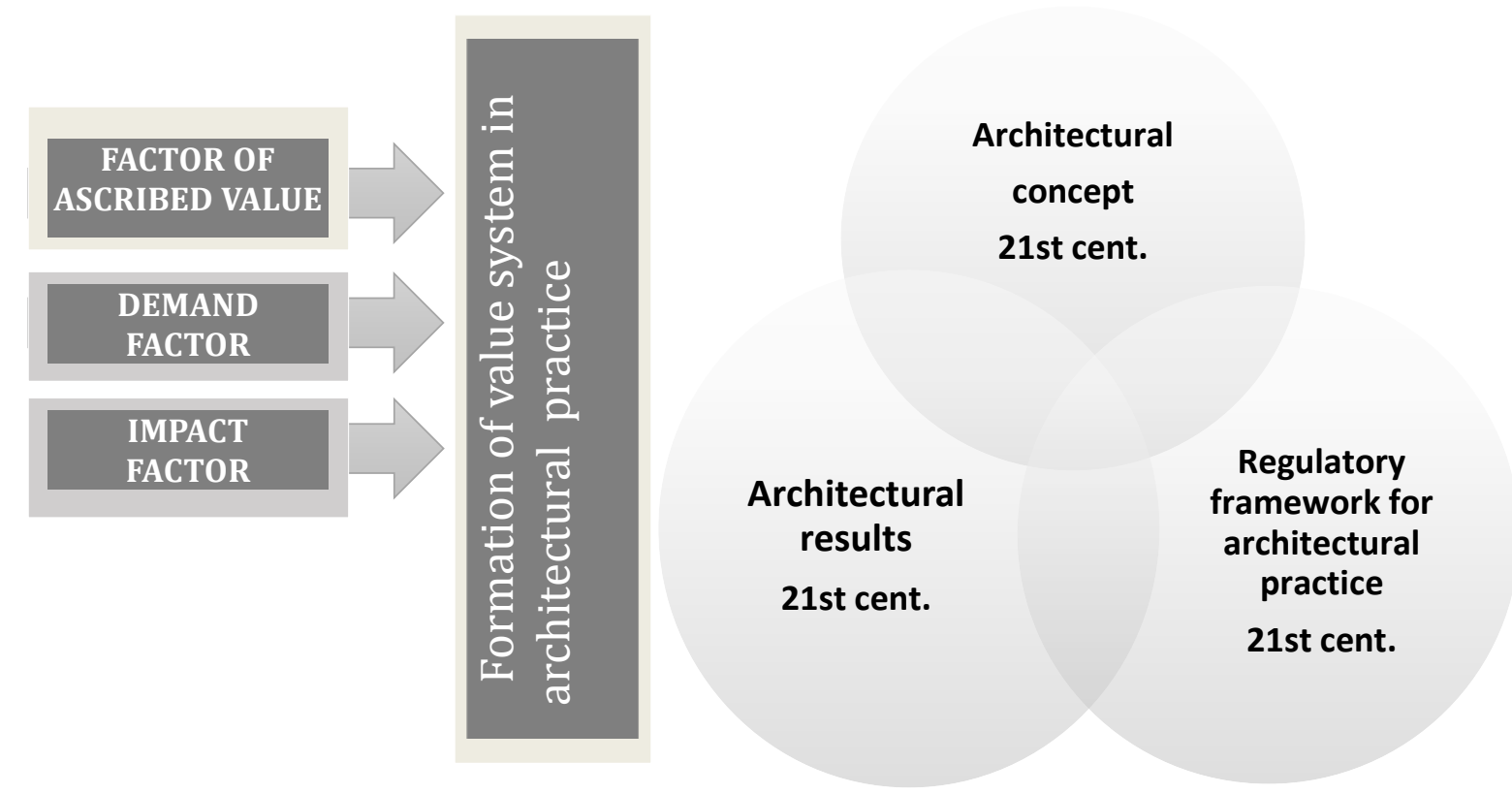

Fig. 3.1. Analysis of the factors contributing to value orientation in the categories of value orientation within practice processes in the $21^{\text {st }}$ century.

The data on the organization of the modern practice, industry research and practice statistics in Latvia since 2007 are summarized, including the main conclusions on the structure and statistics of the professional environment. The author summarizes the materials on the measures and definitions introduced in Latvian since 1991 that define the environment of architectural practice in the $21^{\text {st }}$ century and ensure that dissemination of the postulated values is promoted and controlled. The distinction between the systems dedicated to architectural quality and those dedicated to practice quality is made, highlighting cultural policies of creative industries, legislative regulation of architecture and practice and social process of value reconciliation as the main intentional types of value orientation (Fig. 3.2). 


\section{Purposeful formation of value orientation}

Cultural policy

Legal framework

Reconciliation of stakeholder interests

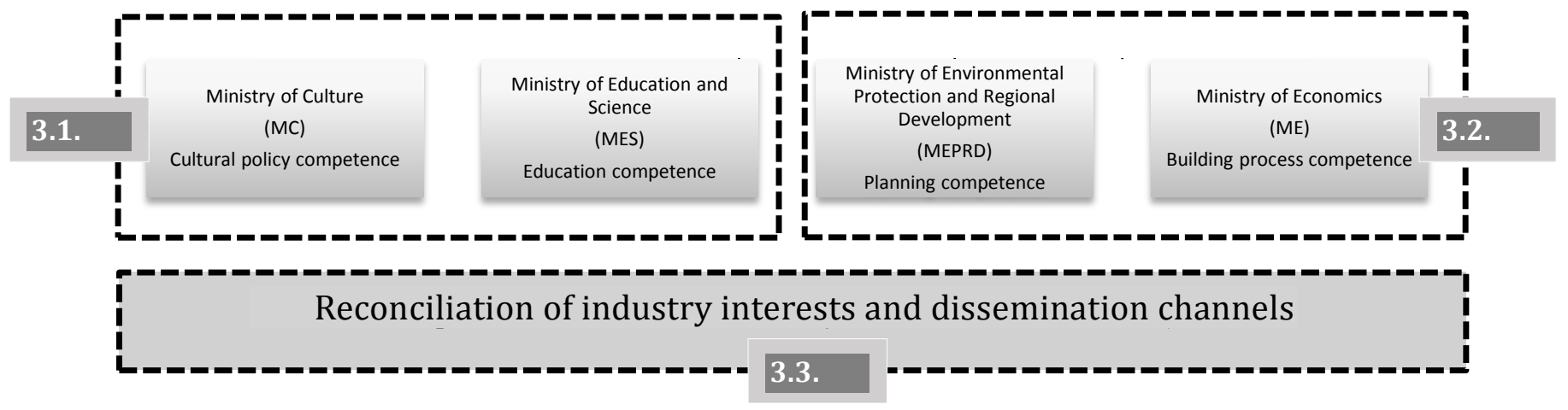

Fig. 3.2. Purposeful formation of value orientation in architectural practice

Predeterminable typological structuring of practice processes is applied in the research, the empirical research data included in the sub-chapter illustrate different identified priorities, which are initially set as the greatest value within the institutionalized framework of each process. The selection of a practical process to be analyzed was made on the basis of the theoretical analysis conducted within the Thesis, results of the surveys and expert interviews, it is the authorial interpretation of the most typical contexts in value orientation in general, as well as the challenges in the Latvian architectural practice since 1991. The analysis in the selected systems is performed using a single method at a first approximation and different methods during in-depth investigation. The value systems considered in the practice processes are first analyzed in value conception, value criteria and regulatory framework modules, which were selected for analysis in Chapters 1 and 2. In the empirical part of research, the research methods are adapted for the context of each system in accordance with the main research questions put forward.

In Sub-chapter 1 of Chapter 3 the author performs functional analysis of architectural value dissemination and management model in cultural policies. The most important issues and definitions forming value orientation are considered within political industry guidelines - the documents that set tasks for the state and municipal institutions.

In the practical research on this type of value orientation, a typical insight into ascribed value, demand and impact factors is provided by an in-depth analysis of professional awards. The conclusions on value orientation dissemination trends in promotion of industry values and public communication are made.

Sub-chapter 2 of Chapter 3 presents functional analysis of architectural value dissemination and management model within the regulatory framework for architectural and construction processes. The vital issues and definitions forming value orientation are analyzed in legislative enactments, in-depth research on the 
building process regulatory framework and supervision of the architect's practice is conducted in the context of value orientation.

In the practical research on this type of value orientation, a typical insight into ascribed value, demand and impact factors is provided by the case study of territory development and planning and functional analysis of obligatory further education system. It is considered how visions and standards in the development of new territories are implemented in practice. The territory typical for a certain location and time period is the object of value orientation research, whose development is regulated and is supposed to meet certain standards. The interaction of architectural values and market conditions in the development of Mārupe private sector is analyzed within the urban development value system.

The idea about the need for life-long learning in the context of rapid change underlying professional further education system ensures productive work of a person in one's profession, it has become a self-evident and inherent element of practice. Analysis attests that the entire society, as well as architects, recognize the value of professional advancement. The idea of professional further education is popular, it is seen as a type of intentional value orientation with a large growth potential.

The main principles and the volume of the professional architectural further study program implemented in Latvia for more than two years are determined by a single legal regulation for all practicing construction specialists. The non-compliance of the unified system to the needs of diverse target audience of architectural service providers is the main challenge. The main issues relate to recognition of compliance to formal requirements, availability of seminars and thematic content quality.

The structure of further education program can be modified, comprehensively analyzing the forms, methods and modes of professional advancement of an architect. At present, widely available forms of information mining are used and keep developing, rather than the forms of information exchange, which have the potential to improve the level of knowledge and skills in the local practice. Promoting practical experience exchange among the colleagues from different generations and activity areas, a further education platform may have the potential to become a forum for circulation and exchange of information and may transform the accumulated practice related challenges into opportunities much quicker than it is happening now.

Sub-chapter 3 of Chapter 3 functional analysis of architectural value dissemination and management model within the social process of value reconciliation. In the area of industry interest reconciliation, value orientation is formed by interaction between the professional identity of an architect and an individual pursuing a definite aim with representational rights to interfere with the creative work of an architect. The formal process of introduction of architectural criteria, value category management performance and its effect on value orientation are analyzed within contemporary architectural practice processes typologically 
determined within value systems in Latvia in 1991-2017.

In the practical research on this type of value orientation, a typical insight into ascribed value, demand and impact factors is provided by an in-depth analysis of institutionalized value dissemination in architectural heritage management, architectural sketch competitions and social processes of interest reconciliation. The existing procedures within these processes, actual performance and their impact on the quality of architecture and professional services are analyzed.

Evaluating the composition and practical application of value orientation purposefully designed to complete value related tasks in the cultural policies, it is concluded that it is best to analyze the set values and the ways to promote them considering the priority tasks set in the planning documents. The quality of architecture and the built environment is set as the greatest value in the cultural policy. Although architecture is positioned as an important element of culture, currently the legal framework for the industry is not legally bound to the cultural policy. At the same time, the industry management system comprising state and municipal institutions is well established; it was recognized as having a considerable impact on practice in the survey (Appendix 7). Practice related performance of the competition promotion system cannot be assessed due to the lack of data, however, the issue is mentioned as highly topical in many studies on industry development. The state provides and maintains an internationally accredited professional education system. In turn, value promotion and industry communication system in the cultural policy context is developing, providing support for participation in selected recognized international forums, locally supporting various cultural activities, tasks and events, funding research, as well as recognizing achievements by granting awards.

In general, the national cultural policy plays a role in ensuring and increasing architectural practice quality, still, its direct impact on practice cannot be objectively assessed or it is comparatively small. In the survey, architects point out that they are proud of their own and their colleagues' achievements, however, they find pleasure in searching for solutions, which they see as their primary professional task. An important part of the daily cultural policy activities consists in educating the wider public, selection of the samples of successful architecture using a set of changeless values. Analysis of industry awards illustrates that primary focus is made on the role of architectural design, disregarding other aspects of value orientation and ignoring the circumstances where the objects evolve. The research demonstrates that there is a fierce competition in the field of awards, because their range has developed both qualitatively and quantitatively. Growth in numbers and segmentation by area attests this phenomenon as a market demand and as a certain form of impact. Award criteria that become separate nominations attest topicality of some values, e.g. heritage preservation, energy efficiency, wooden architecture and other values.

Evaluating the composition and practical application of value orientation 
purposefully designed to complete value related tasks in the regulatory framework, it is concluded that it is best to analyze the set values and the ways to promote them considering the legislative enactments regulating architecture quality and practice supervision. Legal framework is established as a system of requirements that allow building any element of the built environment provided that the legislative norms are observed. Value orientation is formed by development and control of provisions of law, which have notably developed quantitatively but less so qualitatively. It was discovered that the changes in building regulations in 2014 changed the professional status of an architect in administrative and legal terms and architect's role in the overall construction process. The status of a member of creative profession and the respective rights, obligations and responsibility have interacted with the status of a building process participant and a chartered construction specialist.

In general, the role of regulatory framework in ensuring and increasing architectural practice quality is at the heart of the process and its direct impact on practice is relatively high. In the survey, architects point out that currently normative and legislative aspects are in conflict with architectonic thought, artistic approach, dialogue and professional community culture. Arguments "for the sake of idea" are substituted with the argument "in the name of law" - legal obligations of an architect to perform certain actions, including to advance professionally in compulsory further education. Observations on extremities in law enforcement, deadlocks, increase of administrative load, and increase of the share of useless work are highlighted.

An important part of the daily building process activities aims at interpreting and observing the legislative enactments, however, the analysis of territory development demonstrates the result non-compliant with the criteria established on the theoretical principles. Although legal norms are observed, qualitative results in urban planning also depend on public understanding of the urban planning processes and willingness to cooperate. The case of Mārupe development points at the fact that individual's perception and attitudes towards a definite environment are formed by objective and subjective factors. Such value criteria as connection with external public space and the planned multifunctionality in surrounding territory development were cast off in favor of the criteria defined by funding availability cycles. Architectural quality and aesthetics are understood differently and correspondence to qualitative spatial urban development regularities in the new developments is not a decisive value.

Evaluating the composition and practical application of value orientation purposefully designed to complete value related tasks in interest reconciliation, it is concluded that it is best to analyze the set values and the ways to promote them in the course of development of specific objects. Legal and cultural policy related aspects and assessments by certain individuals (experts, members of the jury) play a role in stakeholder interest reconciliation, however, there is a tendency that communication 
mainly occurs employing legal argumentation, in essence considering the processes and terminology through the prism of rights and duties.

In the survey, architects indicate that overall in their daily work they perceive interest reconciliation as self-evident and assess it both positively and negatively depending on the situation. Simultaneously, survey participants recognize that within these reconciliation processes there are such argumentation side-effects as process formalization, bureaucracy and lack of consent exposed in a variety of forms - between generations, among professionals, between professionals and officials. Considering practice processes, they stress the dominating lack of general critical analysis and lack of consistent, substantiated and general requirements towards work environment. They also note the tendency for stakeholders to avoid responsibility in practice, thus responsibility for the final construction result in architectonic categories is lost.

Table 3.1

Interaction among Forms of Intentional Value Orientation and Value Orientation Impact Factors

\begin{tabular}{|c|c|c|c|c|}
\hline \multirow[t]{2}{*}{$\begin{array}{l}\text { Form of } \\
\text { intentional value } \\
\text { orientation }\end{array}$} & \multicolumn{3}{|c|}{$\begin{array}{l}\text { Factors contributing to value orientation that under } \\
\text { intentional formation of value orientation have } \\
\text { developed in a definite direction and have } \\
\text { influenced architectural practice }\end{array}$} & \multirow[t]{2}{*}{$\begin{array}{l}\text { Manifestation } \\
\text { as a tool in } \\
\text { promoting } \\
\text { values }\end{array}$} \\
\hline & $\begin{array}{l}\text { Factor of ascribed } \\
\text { value } \\
\text { (what is ascribed } \\
\text { the highest } \\
\text { significance) }\end{array}$ & $\begin{array}{l}\text { Demand factor } \\
\text { (what is in } \\
\text { demand) }\end{array}$ & $\begin{array}{l}\text { Impact factor } \\
\text { (what tools are } \\
\text { used to cause } \\
\text { impact) }\end{array}$ & \\
\hline $\begin{array}{l}\text { 1. Cultural } \\
\text { policies of the } \\
\text { industry }\end{array}$ & $\begin{array}{l}\text { Criteria of } \\
\text { architectonic values } \\
\text { and diversity of } \\
\text { other criteria, } \\
\text { interaction and } \\
\text { heterogeneity of } \\
\text { priorities }\end{array}$ & $\begin{array}{l}\text { According to } \\
\text { the level of } \\
\text { attention, } \\
\text { recognition, } \\
\text { publicity }\end{array}$ & $\begin{array}{l}\text { Visual } \\
\text { representation, } \\
\text { expert opinion }\end{array}$ & Awards \\
\hline $\begin{array}{l}\text { 2. Regulatory } \\
\text { framework for } \\
\text { architecture } \\
\text { and practice }\end{array}$ & Normative criterion & $\begin{array}{l}\text { Documents } \\
\text { reconciled with } \\
\text { stakeholders }\end{array}$ & $\begin{array}{l}\text { Disciplinary } \\
\text { measures }\end{array}$ & $\begin{array}{l}\text { Institutional } \\
\text { control }\end{array}$ \\
\hline $\begin{array}{l}\text { 3. Social process } \\
\text { of value } \\
\text { reconciliation }\end{array}$ & Polysynthetic & $\begin{array}{l}\text { Timing budgets } \\
\text { that promote } \\
\text { the deficit of } \\
\text { other } \\
\text { resources }\end{array}$ & $\begin{array}{l}\text { Legislative } \\
\text { argument }\end{array}$ & $\begin{array}{l}\text { Procedures, } \\
\text { institutional } \\
\text { opinions, } \\
\text { media }\end{array}$ \\
\hline
\end{tabular}


Analysis of the process of architectural heritage recognition and preservation focuses on essential differences between the desired and the existing. Lack of common understanding is recognized as the main problem, not only concerning the value to be preserved in the objects of heritage, but also the pace of architectural and building processes, which largely depends on coordination issues. Analysis of architectural competitions organized in the historical center of Riga points at inefficiency and formal nature of the developed system. Analysis of the public hearing procedure demonstrates wide public involvement opportunities that influence creative and technical processes of architecture.

Summarizing the findings on interaction among value orientation forming and contributing factors, the summary is compiled (Tab. 3.1).

The number of evaluated systems is considered sufficient in order to draw conclusions on the impact of contingent and purposefully organized processes on value orientation in the architectural practice in Latvia. 


\section{CONCLUSIONS}

1. The most outstanding achievements in architecture are accomplished by observing clear professional value principles, at the same time, the process of their evolvement is facilitated by a number of factors. Uneven development and global socio-economic changes that are underway since the end of last century have conditioned the growing uncertainty in the general development of the industry. Changes in the factors of ascribed value, demand and forms of impact are changing the circumstances where architectural values and spatial environment in general are created, and this calls for the need to reconsider value criteria of the professional practice.

2. The main factors of humanistic conscience - ideas, things and people - also determine the categories in the systematization of architectural practice. According to the division made within axiological research, there are three interacting value categories in architectural practice - architectural concept, architectural result and regulatory framework for architectural practice. The defined division allows for detailed analysis of contingent events and intentional processes that influence modern value orientation of architectural practice.

3. Value orientation in architectural practice documented in the historical sources manifested differently until the end of the $19^{\text {th }}$ century, in the $20^{\text {th }}$ century and $21^{\text {st }}$ century. The differences in all three value categories are manifested with respect to both the conceptual content of professional value criteria and their dissemination and practical implementation. The architectural practice environment in the $2^{\text {st }}$ century is characterized by the tendencies for institutionalization of value dissemination, interaction between the administrative mechanism and the construction industry and the growing concern for interest reconciliation.

4. Since the origins of human civilization, professional value orientation in architecture has developed in the discussion of the value ideas, in the $21^{\text {st }}$ century it is still based on the necessity to meet the needs of the wider public. Along with the growing population and increasing rate of information exchange, differences in value conceptions and great opportunities to choose promote stylistic diversity of the built environment, reduce the role of style and develop a viewpoint for complex assessment. In the context of needs, the ascribed value in the Latvian architectural practice is characterized by understanding of the specifics of the construction process and regulatory compliance. 
5. Professional value orientation, which has been known since the times of Ancient Rome, has evolved within the category of architectural result. In the $21^{\text {st }}$ century, it is still based on the Vitruvian Triad and aesthetic, functional, economic, environmental and social criteria of architecture. Affirmation of the value of contemporary architecture and heritage is made in manifests, canons, value recording registers, professional awards, publications, thematic exhibitions and other forms of assessment. In the context of market change, the demand in the Latvian architectural practice is characterized by value plurality, fragmentation and segmentation, understanding of the conformity of the resource consumption and reputation with a definite market segment is playing an increasing role.

6. Professional value orientation, which since the $12^{\text {th }}$ century has been forming within the category of regulatory framework for architectural practice, is based on the body of legal and administrative instruments regulating construction. In the $21^{\text {st }}$ century, the range of instruments of administrative control has considerably widened and has become an inherent part of architectural practice. In the context of interest reconciliation, forms of impact in the Latvian architectural practice are characterized by procedures of conformity criteria control that are attributable to the aspects of ensuring architectural quality and regulated profession management.

7. Contingent professional value orientation in the Latvian architectural practice since the 1990s is connected with the political context of the state on the European scale (accession to the European Union, global economic crisis, etc.). Design technologies are constantly improving, the range of building materials is constantly growing and building technologies are developing rapidly. Some norms and regulations connected with building safety have significantly influenced value orientation in the Latvian architectural practice.

8. Formation of intentional professional value orientation in Latvia is implemented using impact instruments that are based on the cultural policy, which are connected with the legislative enactments or which realize communication among the stakeholders. Clear value argumentation, adoption of different points of view, ability to adapt, cooperate and synthesize are playing ever more important role in the daily practice. Purposefully established institutional systems often operate out of touch with the practical topicalities, assessment criteria are being formalized, promoting bureaucracy rather than the quality of architecture.

9. In the official cultural policy in Latvia, architectural practice is defined as a creative industry. Basic principles of the cultural policy are mainly actualized in visions and are exposed as measures in supporting architecture. According to the 
basic principles of the value theory, the information base of the cultural policy comprises the values shaping professionally idealistic conscience, which are based on the respected opinions on the worth of the modern architecture. This form of intentional value orientation in architectural practice is assessed as intermediated but significant.

10. Regulatory framework for architectural practice in Latvia is mainly manifested as the attempts to control compliance with building codes and legal aspects of architect's practice. Value status of regulatory framework has developed in connection with the circumstances that have promoted expansive checking of normative compliance and tighter control of practice. This form of intentional value orientation in architectural practice has been assessed as particularly intense.

11. In the Latvian architectural practice, social integration of the conception of value is mainly connected with individual interests and provision of the public rights for qualitative built environment, ensuring both supervision of professional values and the opportunity to implement civic and professional activity. Interaction of the conceptions of value most frequently may cause conflict within the development projects of public significance, in general, it concerns practice on a large scale. Impacts promote establishment of interest groups and actualize the need for public relations skills. This form of intentional value orientation in architectural practice has been assessed as growing.

12. The most significant impact on practice value orientation is imposed by the parties involved in evolvement of architecture - commissioners, civil engineers, engineers, officials and architects. Critical discussions about the role and status of an architect in the environment development have been topical since the first historical records on architectural practice. The factors that compromise the role and status of an architect in the modern architectural practice include the contradictions in the requirements put forward, unpredictable volume of commission, inadequate work remuneration, insufficient qualification and technical capacity.

13. Consistent professional advancement has become a purposefully organized form of value orientation with a good growth potential in the context of modern challenges. Within the existing professional further education programs, the conception of value does not receive sufficient attention. The main part of program curriculum is dedicated to the reaction to the existing practice related topicalities and the studies of the legislative enactments. 


\section{LIST OF SOURCES AND LITERATURE}

\section{Books}

1. Albrow, M. Sociology: The Basics. London; NY: Routledge, 1999. 218 p. ISBN-10: 0415172632 .

2. Architectural theory from the Renaissance to the present (with a pref. by Bernd Evers; in cooperation with the Kunstbibliothek der Staatlichen Museen zu Berlin). Köln: Taschen, 2006. $575 \mathrm{p}$.

3. Ašmanis, M. Politikas terminu vārdnīca. Rīga: Zvaigzne ABC, 1999. 128 lpp.

4. Bachelard, G. The poetics of Space. La poétique de l'espace. Paris: Presses Universitaires de France, 1958. Penguin Books, 2014. 268 p. ISBN 9780143107521.

5. Ballantyne, A. What is Architecture? New York: Routledge, 2001. 224 p. ISBN-13: 9780415256261.

6. Baudrillard, J. The Mirror of Production. New York: Telos Press, 1975. 167 p.

7. Bergevoet, T., Van Tuije, M. The Flexible City. Sustainable solutions. Rotterdam: Nai010 publishers, 2016. 222 p. ISBN 9789462082878.

8. Bērks, P. Kultūru hibriditāte. Rīga: Mansards, 2003. 148 lpp. ISBN 9789934120206.

9. Blumberga, A. (red.), Blumberga, D. Sistēmiskas domāšanas integrēšana vides politikā. Rīga: Rīgas Tehniskās universitātes Vides aizsardzības un siltuma institūts, 2010. $210 \mathrm{lpp}$. ISBN 978-993.

10. Briedis, R. (red.) Cilvēki un notikumi latviešu zemēs no ledus aiziešanas līdz Latvijas valstij. Rīga: Neputns, 2018. 2070 lpp. ISBN 9789934565571.

11. Buka, O., Krastiṇš, J., Strautmanis, I., Lejnieks, J. Latvijas arhitektūras meistari. Rīga: Zvaigzne ABC, 1975. 286 lpp. ISBN 9984040593.

12. Cabrera, J. Netarchy. Beyond the Hierarchy. Leipcig: Amazon Distribution, 2016. 185 p. ISBN 9781520715827.

13. Canizaro, V. Architectural Regionalism: Collected Writings on Place, Identity, Modernity, and Tradition. New York: Princeton Architectural Press, 2007. 496 p. ISBN: 9781568986165.

14. Celmina, I. Rìgas pārvalde astonnos gadsimtos. Rīga: SIA Rīgas nami; Rīgas vēstures un kuǵniecības muzejs, 2000. 352 lpp. ISBN 9984911632.

15. Collins, P. Architectural Judgement. London: Faber \& Faber, 1971. 220 p.

16. Crang, M. (ed.) Thinking Space. Routledge: 2000. 400 p. ISBN-13 9780415160162.

17. Cumtor, P. Thinking Architecture. Basel: Birkhäuser, 2006. 96 p. ISBN 9783034605854. 
18. Daija, P. Apgaismība un kultūrpārnese. Latviešu laicīgās literatūras tapšana. Rīga: LU Literatūras, folkloras un mākslas institūts, 2013. 270 lpp. ISBN 9789984893068.

19. Dambis, J. Kultūras pieminekḷ aizsardzība. Rīga: VKPAI, 2017. 72 lpp. ISBN 9789934863035.

20. Dambis, J. Kultūras pieminekḷu uzmērojumi 1921-1965. Rīga: VKPAI, 2018. 15 lpp. ISBN 9789934863042.

21. Deamer, P. (ed.) The Architect as Worker: Immaterial Labor, the Creative Class, and the Politics of Design. London: Bloomsbury Academic, 2015. 296 p. ISBN 9781472570499.

22. Deamer, P. (ed.) Architecture and Capitalism: 1845 to the Present. New York: Routledge, 2014. 264 p. ISBN 9780415534888.

23. Dexler, H., El Khouli, S. Holistic Housing. Munich: Institut fur Architektur-Dokumentation GmbH\&Co.KG, 2012. 74 p. ISBN 9783920034782.

24. Diamond, J. Collapse: How Societies Choose to Fail or Succeed. New York: Penguin, 2005. 590 p. ISBN 9780670033379.

25. Dimants, A., Broks, J., Raudseps, P. Dzīve ir sacensība: Jāṇa Āboltinga mantojums. Rīga: AM aǵentūra; Latvijas Tirdzniecības un rūpniecības kamera, 2011. 255 lpp. ISBN 9789984493005.

26. Dobelniece, S. Cilvēks un dzīve socioloǵijas skatījumā. Rīga: LU, 1996. 208 lpp. LNC04000161986.

27. Dovladbekova, I., Zelmenis, D., Eteris, E. Mūsdienu finanšu un ekonomiskā krīze Eiropā un Latvijā: izeju meklējot. Rīga: Rīgas Stradiṇa universitāte, 2011. 104 lpp. ISBN 9789984788876.

28. Dovladbekova, I., Eteris, E., Zelmenis, D. Eiropas Savienības ekonomiskā politika un Latvija. Rīga: Rīgas Stradiña universitāte, 2008. 349 lpp. ISBN 9789984788234.

29. Ducmane, K. Apbalvojumi Latvijas Republikā, 1918.-1940. Rīga: Latvijas vēstures muzejs, 1993. 106 lpp.

30. Dutton, J.A. New American Urbanism: Re-forming the Suburban Metropolis. $1^{\text {st }}$ ed. Milano: Skira, 2000. 223 p. ISBN 888187418.

31. Edbauer, M., Bayer, Ch., Rudiger, J. Ereignisse aus 2000 Jahren hohepunkte der geschichte $=$ Pasaules kultūras un vēstures notikumu enciklopēdija. Compact Verlag Munchen, Rīga: SIA J. V. L., izdevums latviešu valodā, 2008. 724 lpp. ISBN 998405473X.

32. Eisner, S., Gallion, A., Eisner, S. The urban pattern: city planning and design. $6^{\text {th }}$ ed. New York: Van Nostrand Reinhold, 1993. 656 p. ISBN 0442007523.

33. Eko, U. Neglītuma vēsture. Rīga: Jāṇa Rozes apgāds, 2009. 453 lpp. ISBN 9789984232874.

34. Eko, U. Skaistuma vēsture. Rīga: Jāṇa Rozes apgāds, 2009. 438 lpp. ISBN 9789984233123. 
35. Eko, U. The Infinity of Lists. Milan: RCS Libri S.p.A. - Bompiani, 2009. 408 p. ISBN 9780847832965 .

36. Fadels, Ch., Bialika, M., Trilings, B. Četru dimensiju izglītība. Lielvārde: Lielvārds, 2017. 112 lpp. ISBN 9789984115481.

37. Fazio, M., Moffett, M., Wodehouse, L. A World History of Architecture. $2^{\text {nd }}$ ed. London: Laurence King, 2003. 592 p. ISBN 9781856695497.

38. Flores, C. A. H. Symbolism. Encyclopedia of 20th-century architecture. Vol. 3 New York: Fitzroy Dearborn, 2004. 567 p.

39. Foster, M. The principles of architecture: Style, structure and desing. London: New Burlington Books, 1989. 224 p. ISBN 9780792451907.

40. Frampton, K. Modern Architecture (A Critical History). London: Thames and Hudson, 2007. 424 p. ISBN 9780500203958.

41. Frampton, K., Simone, A. A Genealogy of Modern Architecture: Comparative Critical Analysis of Built Form. Zurich: Lars Müller Publishers, 2015. 304 p. ISBN 9783037783699.

42. Friedman, J. Cultural Identity and Global Process. London: Sage Publications, 1994. 270 p. ISBN 9780803986381.

43. Garcia, M. (ed.) The Diagrams of Architecture. Chichester: Wiley, 2010. 320 p. ISBN 8843004131.

44. Grīnberga, L. Celvedis ordeņu vēsturē. Rīga: Zvaigzne ABC, 1999. 154 lpp. ISBN 9984171906.

45. Grīns, R. 48 varas likumi. Rīga: Zvaigzne ABC, 2013. 456 lpp. ISBN 9789934037344.

46. Guba, E. G. The paradigm dialog. California: Sage Publications, 1990. 424 p. ISBN 0803938233.

47. Hall, S. Representation: Cultural Representations and Signifying Practices. London: Sage Publications, 1997. 400 p. ISBN-10: 0761954325.

48. Hall, S. Held, D. Hubert, D (ed.). Modernity: An introduction to modern societies. Malden, MA: Wiley-Blackwell, 1996. 690 p. ISBN 9781557867162.

49. Hall, S., Held, D., McGrew, T (ed.). Modernity and its Futures: Understanding Modern Societies. Cambridge: Polity Press, 1992. 408 p. ISBN 9780745609651.

50. Harari, N. J. Sapiensi. Cilvēces īsā vēsture. Rīga: Zoldnera izdevniecība, 2018. 318 lpp. ISBN 9789934845178.

51. Hartman, R. S. The Hartman Value Inventory. Boston: Miller Associates, 1966. 423 p.

52. Hartman, R. S. The Structure of Value: Foundations of Scientific Axiology. Carbondale and Edwardsvile, Ill.: Southern Illinois University Press, 1967. 384 p. 
53. Haupt, E., Kupitza, M. Marketing and Communication for Architects: Fundamentals, Strategies and Practice. Birkhäuser-Publishers for Architecture, 2002. 125 p. ISBN 9783764365714.

54. Holcmane, V., Lūse, A., Žeivate, I. (sast.) Laikmetīgā arhitektūra Latvijā = Contemporary architecture in Latvia. Jelgava: Al secco, 2013. 303 lpp. Latviešu un anglu val. ISBN 9789984994994.

55. Hollinger, R. Postmodernism and Society. Postmodernism and the Social Sciences. New York: Sage Publications, 1999. 208 p. ISBN-10: 0803946384.

56. Imrie, R., Street, E. Architect Design and Regulation. Wiley-Blackwell, 2011. 349 p. ISBN 9781405179669.

57. Inglehart, R., Welzel, C. Modernization, cultural change and democracy: the human development sequence. Cambridge: Cambridge University Press, 2005. 333 p.

58. Jackson, R. L., Roland, I (ed). Encyclopedia of Identity. Sage Publications, 2010. 903 p. ISBN 9781412979306.

59. Jencks, Ch. Le Corbusier and the Tragic View of Architecture. London: Penguin Books, 1973. 198 p. ISBN 7139441.

60. Jencks, Ch. Modern movements in architecture. New York: Anchor Books, 1973. 432 p. ISBN 9780385025556.

61. Jencks, Ch. The Iconic Building: The Power of Enigma. New York: Rizzoli, 2005. 223 p. ISBN 9780847827569, 9780847827565.

62. Jencks, Ch., Kropf, K. (ed.) Theories and manifestos of contemporary architecture. Second edition. UK: Wiley-Academy, 2006. 378 p. ISBN 9780470014691.

63. Jenkins, P., Forsyth, L. Architecture, participation and society. London; New York: Routledge, 2009. 220 p. ISBN 978-0-415-54723-9, 978-0-415-54724-6.

64. Kincāns, V. Estētikas pamati. Rīga: Latvijas Universitāte, 2003.45 lpp. ISBN 9789984194035.

65. Klein, R. M. The Architect's Guide to Small Firm Management: Making Chaos Work for Your Small Firm. John Wiley \& Sons, 2010. 215 p. ISBN 9780470466483.

66. Klooster, I., Klaus, G.H.D., Forty and Famous. 10 interviews with successful young European architects. Almicar Publishers, 2016. 69 p. ISBN 9789082545807.

67. Kḷaviṇš, M., Zaḷoksnis, J. Vide un ilgtspējīga attīstība. Rīga: Latvijas Universitāte, 2010. 160 lpp. ISBN 9789984452203.

68. Kḷavis, A., Krastiṇš, E., Krauze, E. Nekustamais īpašums Latvijā 1991.-2012. Rīga: Latio, 2013. 384 lpp. ISBN: 9789984497211.

69. Kohlberg, L. Essays on Moral Development, Vol. I: The Philosophy of Moral Development. San Francisco, CA: Harper \& Row, 1981. 441 p. ISBN 0-06-064760-4. 
70. Konig, H., Kohler, N., Kreisig, J., Lutzkendorf, Th. A life cycle approach to buildings. Munich: Institut fur Architektur-Dokumentation GmbH\&Co.KG Regensburg, 2010. 144 p. ISBN 9783920034454.

71. Koolhaas, R., Mau, B. $S, M, L, X L$. New York: Monacelli Press, 1995. 1376 p. ISBN 9783822877433.

72. Kornbau, E. The ABCs of the AEC Industry. Best Practices Publication, ZweigWhite Information Services LLC, 2008. 180 p. ISBN 193415055X, 9781934150559.

73. Kotler, P., Armstrong, G. Principle of Marketing. 15th Edition, Prentice Hall, 2013. 736 p. ISBN-13: 978-0134492513.

74. Krastiṇš, J. Rìgas pilsētas arhitekts Reinholds Šmēlings 1840-1917. Rīga: Rīgas pilsētas arhitekta birojs. 2010. 134 lpp. ISBN 9789984877020.

75. Krastiṇš, J., Spārītis, 0. Architecture of Riga. Eight Hundred Years Mirroring European Culture. Rīga: Nacionālais apgāds, 2005. 179 p.

76. Krastiṇš, J., Spārītis, O., Lancmanis, I., u. c. Vācu arhitekti Latvijā. Rīga: Latvijas Vācu Savienība NVO, 2013. 249 lpp. ISBN 9789984496719.

77. Krastiṇš, J., Strautmanis, I. Lielais Rīgas arhitektūras celvedis. Rīga: Dizaina un drukas apgāds "Puse”, 2002. 376 lpp. ISBN 9789984527611.

78. Krastiṇš, J. Latvijas Republikas būvmāksla. Rīga: Zinātne, 1992. 236 lpp. ISBN 5796608495.

79. Krastiṇš, J., Strautmanis, I., Dripe, J. Latvijas arhitektūra no senatnes līdz mūsdienām. Rīga: Baltika, 1998. 312 lpp. ISBN 99849178035.

80. Kruft, H.W. A History of Architectural Theory from Vitruvius to the present. New York: Princeton Architectural Press, 1994. 707 p. ISBN 1568980018.

81. Krugman, P. R. The Conscience of a Liberal. 2009. 352 p. ISBN 9780393333138.

82. Kundziṇš, P. Latvju sēta. Stokholma: Daugava, 1974. 449 lpp.

83. Kursīte, J. Latvieša māja. Rīga: SIA Rundas, 2014. 590 lpp. ISBN 9789934829727.

84. Kustenmacher, M., Haberer, T., Kustenmacher, W. T. GOTT 9.0 Wohin unsere Gesellschaft spirituell wachsen wird. Munchen: Gutersloher Verlagshaus, Gutersloh, in der Verlagsgruppe Random House GmbH, 2010. 319 S. ISBN 9783641050764.

85. Kūle, M. Phenomenology and Culture. Riga: FSI, 2002. 293 p. ISBN $998462420 X$.

86. Kūle, M., Kūlis, R. Filosofija. Rīga: Burtnieks, 1996. 653 lpp. ISBN 9984912965.

87. Kūle M., Muižniece, L., Vēgners, U. Teodors Celms: fenomenoloǵiskie meklējumi. Rīga: FSI, 2009. 328 lpp. ISBN 9789984624686.

88. Lancmanis, I. Jelgavas pils. Rīga: Zinātne, 2006. 238 lpp. ISBN 9984767558. 
89. Landry, Ch. The art of City-Making. London: Earthscan, 2006. 462 p. ISBN 9781844072453.

90. Lasmane, S., Milts, A., Rubenis, A. Ėtika: jautājumi, risinājumi, atzinumi. Metodiskais lïdzeklis. 3. izd., papild. Rīga: Zvaigzne ABC, 1995. 252 lpp. ISBN 9984560651.

91. Latour, B. Reassembling the Social: An Introduction to Actor-network Theory. Oxford: Clarendon, 2005. 312 p.

92. Lakoff, G., Johnson, M. Metaphors We Live By. Chicago: University of Chicago Press, 1980. Xiii, 242 p. ISBN 0226468011.

93. Lawson, B. How Designers Think: The Design Process Demystified. $4^{\text {th }}$ ed. Amsterdam: Elsevier, 2006. 321 p. ISBN 0750660775.

94. Leach, A. What is Architectural History? Cambridge: Polity Press, 2010. 196 p. ISBN 13:9780745644561.

95. Leach, N. Rethinking architecture. London: Routledge, 2002. 432 p. ISBN 0415128269.

96. Lefaivre, L., Tzonis, A. Architecture and Identity in a Globalized World (Architecture in Focus). Prestel Publishing, 2003. 159 p. ISBN 10:3791329723.

97. Lefebvre, H. The Production of Space. Oxford: Blackwell, 1991. 26 p. ISBN 0631181776.

98. Lejnieks, J. Krampis : Arhitekts A. Kronbergs. Rīga: Neputns, 2011. 260 lpp. ISBN 9789984807744.

99. Leeuwen, J., Timmermans H. J. P. Recent Advances in Design and Decision Support Systems in Architecture and Urban Planning. Dodrdrecht; Boston: Kluwer, 2004. 358 p. ISBN 1402024088.

100. Lejnieks, J. Juris Monvīds Skalbergs : Divkāršais kūlenis : Modernisms - Postmodernisms. Rīga: Pētergailis, 2018. 151 lpp. ISBN: 9789984334615.

101. Lejnieks, J. Patiesa forma : Tīrs stils : Modris Gelzis : Arhitekts. Rīga: Neptuns, 2007. 286 lpp. ISBN 9789984807102.

102. Lejnieks, J. Rīga, kuras nav. Rīga: Zinātne, 1998. 397 lpp. ISBN 10: 5796611917.

103. Lejnieks, J. Marta Staṇa : Vienkārši, ar vērienu. Rīga: Rīgas pilsētas arhitekta birojs, 2013. 118 lpp. ISBN 10: 9984807991.

104. Lejnieks, J., Redberga, Z. (red.) Latviešu arhitektu teorētiskie raksti un manifesti 20. gadsimtā = Latvian Architects: Theoretical Writings and Manifestos in the Twentieth Century. Rīga: Mantojums, 2007. 175 lpp.

105. Lenz, B., Schreiber, J., Stark, Th. Sustainable building services. Munich: Institut fur Architektur-Dokumentation GmbH\&Co.KG Altusried-Krugzell: Kosel GnbH \&Co, 2011. 144 p. ISBN: 9783920034492. 
106. Mako, V., Blagojevic, M. R., Mako, M. V. L. (ed.) Architecture and Ideology. Cambridge Scholars Publishing, 2014. 308 p. ISBN 13: 9781443860826.

107. Mathison, S. Representation, Reporting, Communicating. Encyclopedia of Evaluation. Canada: SAGE Publications; University of British Columbia, 2005. 520 p. ISBN: 9780761926092.

108. Megi, B. Filozofijas vēsture. Rīga: Zvaigzne ABC, 2000. 240 lpp. ISBN 9789984176086.

109. Meinig, D. W., Jackson, J. B. The Interpretation of Ordinary Landscapes: Geographical Essays. Oxford: Oxford University Press, 1979. 255 p.

110. Meyer, A., Kuhlbrodt, S., Aerberhard, B. ETH Zurich lecture course $=$ Architecture - $a$ Synoptic vision = Example of an evolutionary history, a prospectus of developments from 1900 to today. Berlin: Birkhauser Verlag AG, 2008. 22 p. ISBN 9783764388768.

111. Miles, S. Consumerism: as a way of life. London: SAGE, 1998. 186 p.

112. Mintaurs, M. Arhitektūras mantojuma aizsardzības vēsture Latvijā. Jelgavas tipogrāfija, 2016. 252 lpp. ISBN 9789934512896.

113. Neufert, E., Neufert, P. Architect's data. $4^{\text {th }}$ ed. Blackwell, 2012. 594 p. ISBN 9781405192538.

114. Oakley, D. The Phenomenon of architecture in Cultures in Change. Elsevier Ltd., 1970. 390 p. ISBN 9780080160757.

115. Obolensky, N. Complex adaptive leadership=Embracing paradox and uncertainty. Farnham: Gover Publishing Limited, 2010. 238 p. ISBN 9780566089329.

116. Palasmaa, J. The eyes of the skin. Architecture and Senses. John Wiley\&Sons, 2012. 126 p. ISBN-13: 9781119941286.

117. Punch, M. Encyclopedia of Urban Studies: Uneven Development. SAGE knowledge, 2009. 1080 p. ISBN: 9781412971973.

118. Redbergs, O., Kalštrēma, I. (red.) Mūsdienu kultūras stāvokḷi = Conditions for Contemporary Culture. Rīga: Megaphone Publishers, 2013. 336 p. ISBN 9789934819209.

119. Restaurētie kultūras pieminekli Latvijā 2016. VKPAI, 2017. 71 lpp. ISBN 9789934193064.

120. Rokeach, M. The Nature of Human Values. New York: Free Press, 1973. 438 p.

121. Rokeach, M. Understanding Human Values: Individual and Societal. New York: Free Press, 1979. $322 \mathrm{p}$

122. Rubenis, A. 20. gs. kultūra Eiropā. Rīga: Zvaigzne ABC, 2004. 456. lpp. ISBN 9984044475.

123. Rubenis, A. Ėtika XX gadsimtā: Praktiskā Ētika. Rīga: Zvaigzne ABC, 1996. 222 lpp.

124. Sadri, H. (ed.) Neo-liberalism and the Architecture of the Post Professional Era. Springer: 2018. 366 p. ISBN 9783319762678. 
125. Sadri, H., Sadri, S. Z. Architecture, City and Human Rights. Centre for Habitat Studies, Girne American University, 2018. 70 p. ISBN 9781365953910.

126. Sancho Pou, E. Function follows strategy. Architects' Strategies from the Fifties to the Present. Detail, 2016. 194 p. ISBN 9783955531966.

127. Sanoff, H. Community participation methods in design and planning. New York: Wiley, 2000. 320 p. ISBN-10: 9780471355458.

128. Scheler, M. Problems of a Sociology of Knowledge. London: Routledge \& Kegan Paul, 1980. 239 p. Translated by Manfred S. Frings. ISBN 0710003021.

129. Schumacher, P. The Autopoiesis of Architecture: A New Agenda for Architecture. Vol. II. UK: A John Wiley and Sons, Ltd., 2012. 774 p. ISBN 9780470666166.

130. Schumacher, P. The Autopoiesis of Architecture: A New Framework for Architecture. Vol. I. UK: A John Wiley and Sons, Ltd., 2011. 461 p. ISBN 9780470772980.

131. Schwarch, S. L, Luycx, K., Vignoles, V. I. Handbook of identity, theory and research. Structures and process. New York: Springer, 2011. 998 p. ISBN-10: 1461451027.

132. Senākā tehniskā universitāte Baltijā - laikmeti un personības. Rīga: RTU, 2012. 156 lpp.

133. Sharmer, 0. C. Theory U: Leading from the Future as it Emerges. San Francisco, CA: Berrett-Koehler Publishers, 2009. 531 p. ISBN 9781576758663.

134. Sharmer, 0. The Essentials of Theory U: Core Principles and Applications. San Francisco, CA: Berrett-Koehler Publishers, 2018. 168 p. ISBN 9781523094400.

135. Siliṇš, E. I. Lielo patiesību meklējumi. Rīga: J. V. L., 2008. 510 lpp. ISBN 9984051862.

136. Sitte, C. The Birth of Modern City planning. Mineola, NY: Dover publications, 1986. 440 p. ISBN 0486451186.

137. Smith, T. G. Vitruvius on Architecture. New York: The Monacelli Press, Inc., 2010. 232 p. ISBN 1885254989.

138. Šteinberga, A., Tunne, I. Jauniešu pašizjūta un vērtības. Rīga: RaKa, 1999. 128 lpp. ISBN13: 9789984151618.

139. Strautmanis, I. Dialogs ar telpu. Rīga: Liesma, 1977. 136 lpp.

140. Strautmanis, I. Latviskā telpa. Rīga: RTU Izdevniecība, 2011. 157 lpp. ISBN 9789934101410.

141. Strautmanis, I. Māksla arhitektūrā. Rīga: Liesma, 1982. 103 lpp.

142. Strautmanis, I. Profesija - visa dzīve. Rīga: Liesma, 1981. 111 lpp.

143.Symes, M., Eley, J., Seidel, A.D. Architects and their practices: a changing profession.Oxford: Butterworth Architecture, 1995. 223 p. ISBN-13: 9780750612999. 
144. Šusts, V. Telpas uztvere un kompozīcija. Rīga: Zvaigzne ABC. 127 lpp. ISBN 9984360024.

145. Taurens, J. Konceptuālisms Latvijā: Domāšanas priekšnosacījumi. VKKF, 2014. 320 lpp. Mīkstais sējums. ISBN 9789934512322.

146. Thilo, E., Esig, N., Hauser, G. Green building certification systems. Munich: Institut fur Architektur-Dokumentation GmbH\&Co.KG Regensburg: Aumuller Druck, 2011. 143 p. ISBN 9783920034546.

147. Tschumi, B. Architecture Concepts: Red is Not a Color. NY: Rizzoli International publications, Inc., 2012. 774 p. ISBN 13: 9780547837977.

148. Tzonis, A., Lefaivre, L. Architecture of Regionalism in the Age of Globalization: Peaks and Valleys in the Flat World. London; New York: Routledge, 2012. 232 p.

149. Van Schaik, L. Mastering Architecture. John Willey\&Sons, 2005. 248 p. ISBN 0470092424.

150. Van Schaik, L. Spatial Intelligence. John Willey\&Sons, 2005. 206 p. ISBN 9780470723227.

151. Van Schaik, L., London, G., George, B. Procuring Innovative Architecture. Routledge, 2010. 240 p. ISBN 13: 9780415429412.

152. Vēbers, M. Protestantiskā ètika un kapitālisma gars. Rīga: LU FSI, 2004. 303 lpp.

153. Veinberga, S. Masmediji. Prese, radio un televīzija. Rīga: Zvaigzne ABC, 2004. 358 lpp.

154. Venturi, R. Compexity and contradiction in Architecture. China: Oceanic Graphic Printing, Inc., 1966. 136 p. ISBN 9780870702822.

155. Vilbers, K. İsa visaptverošā vēsture. Rīga: Jumava, 2011. 408 lpp. ISBN 9789984389332.

156. Vilbers, K. Visaptverošā teorija. Rīga: Jumava, 2010. 232 lpp. ISBN 9789984387505.

157. Vīnbergs, V., Bajārs P., Lejnieks J. $V^{*} X$ Latvijas arhitektūra kopš 1991. gada. Nucleus: 2011. 192 lpp. ISBN 9789984492360.

158. Vitgenšteins, L. Loǵiski filosofiskais traktāts. Rīga: Liepnieks un Rītups. 304 lpp. ISBN 9789984960920.

159.Vitruvius, P. M. Ten Books on Architecture. Amazon Kindle Edition. Digireads.com Publishing, 2009. 338 p. ISBN 1428080643.

160. Watson, N. Postmodernism and Lifestyles. The Routledge companion to postmodernism. $2^{\text {nd }}$ ed. London; New York: Routledge, 2007. 65 p.

161. Wellmer, A. The persistence of modernity: essays on aesthetics, ethics, and postmodernism. Cambridge, Mass: MIT Press, 1991. 200 p.

162. Whiteley, N. Design for society. London: Reaktion Books, 1993.194 p. ISBN: 9780948462658. 
163. Wittkower, R. Architectural Principles in the Age of Humanism. 4th ed. London: Academy Ed., 1988. 160 p. ISBN 0856708755.

164. Yaneva, A. Mapping controversies in architecture. Routledge, 2012.144 p. ISBN 9781409426684.

165. Yaneva, A. The making of a building: A pragmatist approach to architecture. Peter Lang Publishers, 2009. 227 p. ISBN 13: 9783039119523.

166. Zeile, P. Dzīves patiesībai un skaistumam. Rīga, 1967. 328 lpp.

167. Zeile, P. Estētiskā doma Latvijā līdz 1940. gadam. Rīga, 1976. 507 lpp.

168. Zeile, P. Personība un vērtības. Rīga, 1979. 266 lpp.

169. Zībārte, I. (red.) Process I. Laikmetīgās arhitektūras grāmata Nr. 1. Arhitektūras Veicināšanas Fonds, Jelgavas tipogrāfija, 2008. 223 lpp. ISBN 9789984394107.

170. Zībārte, I. (red.) Process II. Laikmetīgās arhitektūras grāmata Nr. 2: Free Entry. Arhitektūras Veicināšanas Fonds, Jelgavas tipogrāfija, 2009. 142 lpp. ISBN 9789984399027.

171. Zībārte, I. (red.) Process III. Jaunā arhitektūra Latvijā. Arhitektūras Veicināšanas Fonds, Jelgavas tipogrāfija, 2013. 221 lpp. ISBN 9789984496900.

172. Zumthor, P. Atmospheres: architectural environments, surrounding objects. Basel, Boston: Birkhauser, 2006. 75 p. ISBN 9783764374952.

\section{Articles in article collections and periodicals, research}

173. Ameloskina, N. Rīgas vēsturiskā centra kultūrvēsturiskās vides saglabāšanas koncepcijas (1948-2006). Latvijas Zinātņu Akadēmijas vēstis, 2015, 69. sēj., 3./4. nr., 4.-20. lpp.

174. Andersson, J. E. Architectural Competitions as a Municipal Instrument for Innovating Space for the Ageing Society: The Dynamics of Three Competitions. Proceedings of 5th International Conference on Competitions, Delft, 2014, pp. 63-78.

175. Baltijas Konsultācijas SIA, Konsorts SIA. Latvijas radošo industriju darbība un priekšnoteikumi nozares mērkstiecīgai attīstībai, 2013, 224 lpp.

176. Baron, J., Spranca, M. Protected values. Organ Behav Hum Decis Process, 1997, 70 (1), pp. 1-16.

177. Beauregard, R. A. Urban Agglomeration. Encyclopedia of Urban Studies, University of Wisconsin, Green Bay, 2010, pp. 839-840.

178. Bērzkalns, P. Nacionālais stils celtniecībā. Daugava, 1938, Nr. 9, 845.-860. lpp.

179. Brenner, N., Theodore, N. Preface: From the "New Localism" to the Spaces of Neoliberalism. Antipode, 2002, Vol. 34 (3), pp. 341-347. 
180. Brown, L. Architectural education: A new paradigm for the future. Architecture of Architecture, 2017, Vol. 1, pp. 106-108. ISSN 2575-7008.

181. Bryant, Ch., Rodgers, C. The changing Forms and Values of Architecture Practice. Architectural Design, 2018, Vol. 88 (5), pp. 6-13. DOI: 10.1002/ad.2336.

182. CABE. The Value Handbook: Getting the most from your buildings and spaces. Commission for Architecture and the Built Environment, 2006, pp. 49-64.

183. Carmona, M., De Magalhães, C., Edwards, M. Stakeholder Views on Value and Urban Design. Journal of Urban Design, 2002, Vol. 7(2), pp. 145-169.

184. Cirtautas, M. Urban Sprawl of Major Cities in the Baltic States. Architecture and Urban Planning, 2013, Vol. 7, pp. 72-79. ISSN 1691-4333.

185. Darbina, G., Lūse, A. Development of suburbs in the context of post-socialist consumption models: The case of Pierīga. European Integration Studies, 2012, No. 6, 101110. ISSN 1822-8402.

186. Excolo Latvia SIA. Latvijas arhitektūras nozares statistisks raksturojums. Rīga: LR Kultūras ministrija, 2014, 86 lpp.

187. Frampton, K. Studies in Tectonic Culture: The Poetics of Construction in Nineteenth and Twentieth Century Architecture. MIT Press, Cambridge, Mass., 1995, p. 448. ISBN: 9780262061735.

188. Frampton, K. Towards a Critical Regionalism: Six Points for an Architecture of Resistance. Foster, H. (ed.) The Anti-Aesthetic: Essays on Postmodern Culture, Bay Press, Port Townsen,1983, pp. 16-30.

189. Freiberga, E. European Values and Latvian Identity. National Identity and Vision of Europe. Annals of the European Academy of Sciences and Arts, 2000, Vol. 28, No. 9, pp. $32-$ 38.

190. Frolov, A. Nordic Block. Exibition and catalogue Project Baltia, 2014, p. 37.

191. Grava, S. Anglu u-latviešu pilsētvides terminu vārdnīca. Rīga: Jānna Rozes apgāds, 2006, 320 lpp. ISBN 9984232271.

192. Graves, C. W. Levels of Existence: an Open System Theory of Values. Journal of Humanistic Psychology, 1970, vol. 10 (2), p. 131-155. DOI:10.1177/002216787001000205.

193. Gražulevičiūte-Vileniške, I., Vitkuviene, J. How Rural Becomes Rurban - Rural Manor Residencies in the Urban Context: Lithuanian Case. Architecture and Urban Planning, 2013, Vol. 7, pp. 32-37. ISSN 1691-4333.

194. Groskaufmanis, M., Ozola, E., Skrējāne, A. (red.) The architecture of together and apart: an inquiry into apartment buildings. Latvian Pavilion 16th International Architecture Exhibition La Biennale di Venezia. New Theatre Institute of Latvia, 2018, p. 198. ISBN 9789934195129. 
195. Guilherme, P. Shall we compete? Proceedings of 5th International Conference on Competitions, Delft, 2014, pp. 35-63.

196. Guy, S. Sustainable buildings, meanings, processes, users. Built Environment, 2002, Vol. 28, No. 1, pp. 5-11.

197. Hanovs D. Ievads. Par kultūrām, kopienām un piederību: dialogs mūsdienu Latvijā. Hanovs D. (red.) Dialogs Latvijā: kultūru dažādība, robežas un saiknes. Rīga: Akadēmisko programmu aǵentūra, 2008. 6.-11. lpp.

198. Hanovs, D., Mihailovs, I. J., Tēraudkalns, V. Globalizācija: teorijas un prakses. Rīga, 2008, 100 lpp.

199. Hartman, R. S. Formal Axiology and the Measurement of Values. Journal of Value Inquiry, 1967, Issue 1, pp. 38-46. DOI: 10.1007/BF00149464.

200. Inglehart, R. The silent revolution in Europe: intergenerational change in post-industrial societies. American Political Science Review, 1971, Vol. 65 (4), pp. 991-1017.

201.Inglehart, R. Globalization and postmodern values. The Washington Quarterly, 2000, 23 (1), pp. 215-228. DOI: 10.1162/016366000560665.

202. Inglehart, R. Mapping global values. Comparative Sociology, 2006, 5 (2-3), pp. 115-136.

203. Inglehart, R. Changing values among Western publics from 1970 to 2006. West European Politics, 2008, Vol. 31 (1-2), pp. 130-146.

204. İjabs, I. Pilsoniskā sabiedrība Latvijā : nākotnes perspektīvas. Ozolinna, Ž., UlnicāneOzoliṇa, I (red.). Latvija 2020 : Nākotnes izaicinājumi sabiedrībai un valstij, Rīga: LU Akadēmiskais apgāds, 2008, 141.-154. lpp.

205. Jākobsone, J. Local Identity - Influencing Factors on Cultural Heritage Preservation in Context of Sustainable Development. Kuldiga Case Study. Sustainable Spatial Development, 2011, Vol. 2, pp. 85-89. ISSN 1691-6174.

206. Jencks, Ch. In what style shall we build? Architecture Review, March 2015, pp. 90-100.

207. Keil, R. Common-Sense Neoliberalism: Progressive Conservative Urbanism in Toronto, Canada, Antipode, 2002, Vol. 34, pp. 578-601.

208. Kirby, A. The production of private space and its implications for urban social relations. Political Geography, 2008, Vol. 27, Issue 1, pp. 74-95. ISSN 0962-6298.

209. Krastiṇš, J. Latvijas arhitektūras nacionālā identitāte. Latvijas Arhitektūra, 1989, 5.-20. lpp.

210. Kreiner, K. Paradoxes of architectural competitions: the competition between efficiency, justice and creativity. 26th Annual ARCOM Conference, Association of Researchers in Construction Management, 2010, pp. 441-450. 
211. Lasmane, S. Cita triāde: intelekts, ètika, patība. No iespējamas sarunas ar kolēǵi Ābramu Kleckinu. O. Proskurova (red.), Laiku atšalkas: žurnālistika, kino, politika. Rīga: LU Sociālo un politisko pētījumu institūts, 2010, 4.-10. lpp.

212. Lasmane, S., Šḳilters, J. (red.) Nacionālās identitātes komunikācija Latvijas kultūras telpā. Valsts pētījumu programmas Nacionālā identitāte, Rīga: LU Sociālo un politisko pētījumu institūts, 2011, 224 lpp.

213. Lauku Arhitektu Kopa. Lauku Sēta : Gaile, Z (red.) [katalogs] Lauku Arhitektu Kopas Izstāde, Rīga: Jauno Mākslinieku Klubs, Jān,a Sēta, 1989.

214. Laube, E. Arhitektūras gars atjaunotā Latvijā. Latvijas Arhitektūra, 1939, Nr. 4./5, 111.113. lpp.

215. Laube, E. Kādā ceḷā iegūstama latviski īpatnēja arhitektūra. Raksti par arhitektūru. Linkolna: Vaidava, 1960, 81.-83. lpp.

216. Laube, E. Nacionālā elementa apzināta realizācija celtnieciskā arhitektūrā. Raksti par arhitektūru. Linkolna: Vaidava, 1960. 71. lpp.

217. Lediṇš, H. Arhitektūras uztveres filozofiskie aspekti. Rīga, 1981. 19 lpp.

218. Lejnieks, J. Okupācijas laika arhitektūra Latvijā: Zagtā vai dāvinātā. Māksla, 1990, Nr. 12 (142). 36.-41.lpp.

219. Lešinska, A. Monitorings par sabiedrības informēšana par būvniecības iecerēm atbilstoši Būvniecības likumā noteiktajam, Sabiedriskās politikas centrs PROVIDUS, 2015, 114 lpp. ISBN 978-9934-532-09-2.

220. Liepa, E. Konkurence būvniecības tirgū Latvijā. Konkurences padome: Rīga, 2006, 165 lpp.

221. Litvins, G. Sabiedrības līdzdalība teritorijas plānošanas un būvniecības jautājumos. Sabiedriskās politikas centrs PROVIDUS, 2008, 128 lpp.

222. Lukševics, U., Leitāne-Šmīdberga, L., Jauja, Z., u.c. (red.) Un-written. Exhibition of Latvia at the 14th International Architecture Exhibition - la Biennale di Venezia. Catalogue. Riga, 2014, pp. 349-366.

223. Lūse, A. Konkursa "Ilgtspējīgākā ēka un projekts Latvijā 2013" izvērtēšana. Latvijas Būvniecība, 2013, Nr. 6 (41), 16.-22. lpp.

224. Lūse, A. Latvijas būvnozares konkursu kalendārs. Latvijas Būvniecība, 2013, Nr. 2 (37), 24.-29. lpp.

225. Lūse, A. Konkursa "Ilgtspējīgākā ēka un projekts Latvijā 2014" uzvarētāji. Latvijas Būvniecība, 2014, Nr. 5 (46), 10.-17. lpp.

226. Lūse, A., Holcmane, V. Diskusija "Vai nozares konkursu rezultāti liecina, ka laba arhitektūra ir arī laba būve?". Latvijas Būvniecība, 2013, Nr. 3 (38), 94.-96. lpp. 
227. L Lisicina L. Dzīves baudītāji vai tradicionālisti? Latvijas iedzīvotāju vērtīborientācija "treknajos gados". Škilters, J., Lasmane, S. (red.), Nacionālās identitātes komunikācija Latvijas kultūras telpā, Rīga: LU Sociālo un politisko pētījumu institūts, 2009, 67.-81.lpp.

228. Mako, V. (ed.) Architecture and Ideology. International Conference Faculty of Architecture, University of Belgrade, 2012, pp. 652-662.

229. Maslow, A. H. A Theory of Human Motivation. Psychological Review, 1943, Vol. 50, Issue 4, pp. 370-396.

230. Menon, C., Vandenburgh, D. Who-or What-"Wins" an Architectural Competition? A Model and a Case Study. FORMakademisk, 2014, Vol. 7, No. 1, pp. 1-19.

231. Moore, S. Technology, place and the nonmodern thesis. Journal of Architectural Education, 2001, Vol. 54, Issue 3, po. 130-139.

232. Mueller, R. W. The axiology of Robert S. Hartman: A critical study. The Journal of Value Inquiry, 1969, Vol. 3, Issue 1, po. 19-29.

233. Murray, M., Greer, J., Houston, D. Bridging Top down and Bottom up: Modelling Community Preferences for a Dispersed Rural Settlement Pattern. European Planning Studies, 2009, Vol. 17 (3), po. 441-462.

234. Mūriṇš, S. Pētījums par sabiedrības iesaistes mehānismiem attīstības plānošanā un uzraudzībā vietējā līmenī. Rìgas plānošanas reǵions, 2013, 20 lpp.

235. Neiders, I. Morālā motivācija: vēlmes un iemesli. Filosofija. Rīga: LU, 2005, 687. sējums, 31.-44. lpp.

236. Nikodemus, O., Bell, S., Grīne, I., u.c. The impact of economic, social and political factors on the landscape structure of the Vidzeme Uplands in Latvia. Landscape and Urban Planning, 2005, Vol. 70, Issues 1-2, po. 57-67. ISSN 0169-2046.

237. Nikiforovs, O. Pedagogijas pamati: lekciju kurss - konspekts un kontroluzdevumi klātienes, neklātienes un distanta apmācībai. Rīga: Baltijas Starptautiskā akadēmija, 2008, 136 lpp.

238. Palasmaa, J. Is Finnish architecture losing its direction. Finnish Architecture 2010/2011, Helsinki, 2012, pp. 28-31.

239. Palasmaa, J. Space, Place and Atmosphere: Peripheral Perception in Existential Experience. Lebenswelt, 2014, No.4, pp. 230-245.

240. Pēkšēns, K. Kā varam vēl būvēt? Ekonomists, 1920, 12. sēj., Nr. 9, 255.-229. lpp.

241. Pelše, S. Kultūrainas panorāma. Mākslas Vēsture un Teorija, 2014, Nr. 17, 65.-66. lpp.

242. Pužulis, A., Šķiṇķis P. Pierīgas apdzīvojuma struktūras izpēte, Rīgas plānošanas reǵions, 2009, 20 lpp.

243. Rapaports, A. Arhitektūras jēga. Redbergs, O. (red.). Mūsdienu kultūras stāvokḷi. Megaphone Publishers, 2013, 289.-294 lpp. 
244. Rapaports, A. Arhitektūru var glābt tikai Dievs. Rīgas Laiks, 2012, Nr. 1, 49.-57. lpp.

245. Raz, J. Value incommensurability: some preliminaries. Proceedings of the Aristotelian Society, 1985, Vol. 86 (1), pp. 117-134.

246. Ronn, M. Architectural quality in competitions. A dialogue based assessment of design proposals. FORMakademisk, 2011, Vol. 4, No. 1, pp. 100-115.

247. Ronn, M. Choosing architects for competitions- experiences from the selection of design teams in Sweden. FORMakademisk, 2014, Vol. 7, No. 1, pp. 1-17.

248. Ronn, M., Kazemian, R. Key concepts, Criteria and Quality Judgement in Architecture. Stockholm: KTH Royal Institute of Technology, 2007, pp. 1-21.

249. Rungule, R., Seṇkāne, S. Latvijas iedzīvotāju vērtības pēc Eiropas Sociālā pētījuma datiem. Politiskās, ekonomiskās, sociālās un tiesiskās sistēmas transformācijas Latvijā un pasaulē, Rīgas Stradiṇa universitāte, 2016, 274. lpp.

250. Savage, M., Bagnall, G., Longhurst B. Suburbia and the Aura of Place. Globalization and Belonging, 2010, Chapter 4, pp. 78-105.

251. Scheler, M. Formalism in Ethics and Non-Formal Ethics of Values: A New Attempt Toward the Foundation of an Ethical Personalism. Northwestern University Press, 1973, pp. 5-369.

252. Schwartz, S. H. Universals in the Content and Structure of Values: Theoretical Advances and Empirical Tests in 20 Countries. Advances in Experimental Social Psychology, 1992, 25, pp. 1-65.

253. Scotte, H. The condition of identity in modern architecture, Project International, 2011, No. 30, 193 p.

254. Sīle, V., Sīlis, V. Refleksija par vērtībām tagadnes kontekstā. Akadēmiskā Dzīve 2017./2018., Nr. 54, 72.-84. lpp.

255. Soja, E. W. Regional Planning and Development Theories. Kitchin,R., Thrift, N. (ed.) International Encyclopedia of Human Geography, Elsevier, 2009, pp. 259-270. ISBN 9780080449104.

256. Strautmanis, I. Arhitektoniskās vides emocionāli estētiskā uztvere. Arhitektūra un pilsētbūvniecība Latvijas PSR II: Rakstu krājums, Rīga: Zinātne, 1971, 29.-35. lpp.

257. Strautmanis, I. Par arhitektūras informatīvi emocionālo potenciālu. Pilsētu attīstība un arhitektūra Latvijas PSR, Rīga: Zinātne, 1974, 52.-57. lpp.

258. Strautmanis, I., Grūbe, V. Struktūras jēdziens, tās uztveres iespējas un izmantošana arhitektūras teorijā. Latvijas PSR pilsētu arhitektūra. Rīga: Zinātne, 1979, 34.-47. lpp.

259. Svensson, C. Speaking of architecture. A study of the jury's assessment in an invited competition. Nordic Journal of Architectural Research, 2009, Vol. 22(2/3), pp. 94-107.

260. Šķilters, J., Lasmane, S. (red.) Nacionālās identitātes komunikācija Latvijas kultūras telpā. Rīga: LU Sociālo un politisko pētījumu institūts, 2011, 224 lpp. 
261. Šusts, V. Mājas un mājīgums. Māksla, 1968, Nr. 2 (38), 21.-23. lpp.

262. Šuvajevs, I. Laika raksturojums. Vērtību un identitātes meklējumos, Rīga: LU Filozofijas un sociologijas institūts, 2012, 302 lpp.

263. Taurens, J. Konteksta jēdziens arhitektūras semantikā. Mākslas darbs un komentārs, 2001, Rīga: LEA, 20.-22. lpp.

264. Taurens, J. Mājas: Arhitektūras valoda. Mājas: Pagātnes atmiṇas - nākotnes vīzijas. Rīga: LU Praktiskās filozofijas katedra, 1998, 136.-146. lpp.

265. Taurens, J. Arhitektūras semantika. Demakova, H. (red.), Sarunas III, Rīga: Jaunā akadēmija, 2003, 354.-360. lpp.

266. Taurens, J. Meaning and Context in the Language of Architecture. Place and Locations IV, Studies in Environmental Aesthetics and Semiotics, 2008, pp. 71-82. ISSN 1736-2326.

267. Tostrup, E. Architecture and rhetoric: text and design in architectural competitions, Oslo, 1939-1997. Andreas Papdakis Publisher, 1999, p. 208. ISBN 1901092054.

268. Tračuma, B. Koncertzāle "Lielais dzintars", Kukainīša anatomija jeb Liepājas daudzfunkcionālais centrs "Lielais dzintars" tuvplānā. Latvijas Būvniecība, 2016, Nr. 1, 51.-63. lpp. ISSN 1691-4058.

269. Van de Poel, I. Values in engineering design. Philosophy of technology and engineering sciences, Handbook of the philosophy of science. Elsevier, 2009, Vol. 9, pp. 973-1006.

270. Van de Poel, I. Translating values into design requirements. Philosophy and engineering: reflections on practice, principles and process. Springer, 2013, pp. 253-266.

271. Van de Poel, I. Conflicting Values in Design for Values. Handbook of Ethics, Values, and Technological Design, 2014, pp. 1-23.

272. Van Eyck, A. The Child, the city and the Artist. 1962. Ligtelijn V., Strauven, Fr. (ed.) Aldo van Eyck. Writings, SUN, 2008, p. 159. ISBN: 978-90-8506-262-2.

273. Van Schaik, L. The Practice of Practice: practice based research in Architecture. The Practice of Practice: Research in the Medium of Design, RMIT University Press, 2016, pp. 12-19.

274. Van Schaik, L. Understanding the Practice. Fender Katsalidis: Working Architecture. Uro Publications, 2017, pp. 22-55.

275. Vanags, A., Miķelsone, A., Gubins, S. Latvijas radošo industriju apskats: definīcija, statistika, ekonomika un savstarpējās saiknes. A Baltic International centre for economic policy studies, 2007, $125 \mathrm{lpp}$.

276. Volker, L. Deciding about Design Quality. Value judgements and decision making in the selection of architects by public clients under European tendering regulations. Leiden: Sidestone Press, 2010, pp. 1-6. 
277. Volker, L. Design a design competition: the client perspective. Design research society international conference: design \& complexity, 2011, pp. 1-11.

278. Yaneva, A. Making the Social Hold: Towards an Actor-Network Theory of Design. Design and Culture, 2015, Vol. 1 (3), pp. 273-288. DOI: 10.1080/17547075.2009.11643291.

279. Zeltiṇa L. Latviskā identitāte Eiropas identitātes kontekstā. Humanitārās un sociālās zinātnes, 2006, Nr.10, 94.-99. lpp. ISSN 1407-9291.

280. Zeltiṇa, L. Modernā sabiedrība ilgtermiṇa perspektīvā. Humanitārās un sociālās zinātnes, 2003, Nr. 4, 134.-141.lpp. ISSN 1407-9291.

281. Zigmunde, D. Harmonization of Landscape Aesthetics and Ecology in the Context of Sustainable Planning. Sustainable Spatial Development. Sustainable Spatial Development, Vol. 1, 2010, pp.94-98. ISSN 1691-6174.

282. Zimmels, G. Nauda modernajā kulturā. Latvijas Universitātes raksti. Rīga: LU, 2002, 629. sēj., 12.-38. lpp.

\section{Unpublished works, dissertations and Doctoral Theses}

283. Arhitekta ètikas un profesionālās rīcības kodekss. Latvijas Arhitektu savienības padome. Rīga: Latvijas arhitektu savienības (LAS) arhīvs, 2012. 6 lpp.

284. Arhitektūras nozari regulējošo likumprojektu izvērtējums. Nacionālās arhitektūras padomes darba grupa. Rīga: Latvijas arhitektu savienības (LAS) arhīvs, 2015. $21 \mathrm{lpp}$.

285. Austruma, S. Jauniešu vērtības pātērētājsabiedrībā Latvijā. Promocijas darbs. Rēzekne: Rēzeknes augstskola, 2012.

286. Danovskis, E. Likumu un normatīvo aktu sistēmas hierarhija Latvijā. LU mGaileācību programma "Publiskās tiesības". Rīga: LU, 2016.

287. Liepa-Zemeša, M. Pilsēttelpas attīstība Rīgā. Promocijas darbs. Rīga: RTU, 2011. 204 lpp.

288. Pužulis, A. Robežu loma ǵeogrāfiskajā telpas organizācijā Latvijā. Promocijas darbs. Rīga: Latvijas Universitāte, G̣eogrāfijas un Zemes zinātṇu fakultāte, 2012. 77 lpp.

289. Pūre, I. Sabiedrisko attiecību attīstība un izpratnes dažādība Latvijā (1991-2010). Promocijas darbs. Rīga: Biznesa augstskola Turība, 2013. 193 lpp.

290. Stipre, S. Valsts apbalvojumi Latvijā un to tiesiskais regulejjums. Promocijas darbs. Rīga: Biznesa augstskola Turība, 2014. 255 lpp.

291. Stūre, I. Kultūras un dabas mantojuma aizsardzība un attīstības plānošana. Promocijas darbs. Rīga: LU Akadēmiskais apgāds, 2004. 194 lpp.

292. Taurens, J. Lingvistiskās nozìmes teorijas arhitektūras semantikā. Promocijas darba kopsavilkums. Rīga: LU, Vēstures un zinātnes fakultāte, 2015. 28 lpp. 


\section{Electronic resources}

293. Aksiologija (Аксиология) [tiešsaiste]. www.gtmarket.ru [skatīts 11. 03. 2009]. https://gtmarket.ru/conscepts/6894.

294. Aksioloǵija (Аксиология) [tiešsaiste]. http://dic.academic.ru [skatīts 11.03.2012]. https://dic.academic.ru/dic.nsf/enc_philosophy.

295. Albrow, M. Globalization after Modernization: A New Paradigm for the Development Studies. [online]. in F. J. Schuurman (ed.) Globalization and Development Studies: Challenges for the 21st Century, pp. 21-30. London: SAGE Publications, 2011 [cited 11.11.2014.]. https://journals.sagepub.com/doi/10.1177/0268580904045344.

296. Arhitektūras portāla $a 4 d$ ikgadējā arhitektu aptauja par gada nozīmīgākajiem notikumiem [tiešsaiste 12.04.2015.]. www.a4d.lv/gadaaptauja/2015.

297. Arhitektūras portāla $a 4 d$ ikgadējā arhitektu aptauja par gada nozīmīgākajiem notikumiem [tiešsaiste 12.04.2016.]. www.a4d.lv/gadaaptauja/2016.

298. Austers, I. Swedbank Latvijas Vērtību pētījums sadarbībā ar SKDS [tiešsaiste]. Latvijasvertibas.lv [citēts 09.11.2015.].

http://www.leta.lv/lvbparskats/lvbparskats/press_release.

299. Austers, I., Andersone, M. Īss ziṇojums par Latvijas iedzīvotāju aptauju : Ilgtspējīga attīstība, vērtības un paradumi [tiešsaiste]. Latvijas ilgtspējigas attīstības stratēgija līdz 2030. gadam, 2008 [citēts 11.11.2010.]. http://www.latvija2030.lv/page/242.

300. Balva: Arhitekta pēda. Piešksir kopš 2006.gada Arhitektūras veicināšanas fonds [tiešsaiste]. a4d.lv [skatīts 10.05.2015.].

http://www.a4d.lv/lv/notikumi/janis_lejnieks_sanem_arhitekta_pedu_2006/.

301. Balva: Baltijas Asamblejas balva literatūrā, mākslā un zinātnē [tiešsaiste]. Baltijas Asambleja [skatìts 10.05.2015.]. http://baltasam.org/en/prizes/baltic-assembly-prize.

302. Balva: Jaunie Projekti. Piešksirta 2006.-2008. [tiešsaiste]. Latvijas nekustamo īpašumu darïjumu asociācija [skatīts 10.05.2015.]. http://jaunieprojekti.lv/lv/n ewspaper/33/news/5.html.

303. Balva: Būvin dustrijas gada balva, Mūža ieguldījums būvniecības nozarē, Gada inženieris Latvijā. Piešksir kopš 2013. gada Latvijas Būvnieku asociācija un medijs Latvijas Būvniecība [tiešsaiste]. Buvindustrijaslielabalva.lv [skatīts 10.05.2015.]. http://www.gadabuvinzenieris.lv/BI/aktualitates/.

304. Balva: Eiropas Arhitektūras balva. Piešķir kopš 2006. gada Eiropas Arhitektūras mākslas dizaina un pilsētu studiju centrs [tiešsaiste]. Europeanarch.eu [skatīts 10.05.2015.]. http://www.a4d.lv/lv/notikumi/jauna-eiropas-arhitekturas-balva/.

305. Balva: Eiropas balva par arhitektūras mantojuma saglabāšanu [tiešsaiste]. Heritageportal.eu [skatìts 10.05.2015.]. http://www.heritageportal.eu/NewsEvents/Latest-News/-European-Award-for-Architectural-Heritage-interventionAADIPA.html. 
306. Balva: Energoefektīvākā ēka Latvijā. Piešksir kopš 2011. gada medijs Latvijas Būvniecība, Ekonomikas ministrija un Vides aizsardzības un reǵionālās attīstības ministrija [tiešsaiste]. Energoefektivakaeka.lv [skatīts 10.05.2015.]. http://www.energoefektivakaeka.lv/index.php/home/konkursa-nolikums-2015.

307. Balva: Gada balva dizainā. Pieškị kopš 2008. gada Latvijas Dizaineru savienība [tiešsaiste]. Design.lv [skatīts 10.05.2015.]. http://design.lv/en/gada-balva-dizaina/gadabalva-dizaina-2014.

308. Balva: Gada labākā būve Latvijā. Piešķir kopš 1996. gada Latvijas Būvnieku asociācija [tiešsaiste]. Gadabuve.lv [skatīts 10.05.2015.]. http://gadabuve.lv/index.php/nolikums/.

309. Balva: Ilgtspējīgākā ēka un projekts Latvijā. Piešksir kopš 2008. gada mediji Latvijas Arhitektūra, Latvijas Būvniecība, Latvijas Ilgtspējīgas būvniecības padome un Pasaules Zaḷās būvniecības padome [tiešsaiste]. ipb.lv [skatīts 10.05.2015.]. http://www.ibp.lv/lv/musu-projekti/konkurss-ilgtspejigaka-eka-un-projekts-2014/.

310. Balva: Kultūras izcilības balva. Piešḳir kopš 2014. gada LR Kultūras ministrija [tiešsaiste]. km.gov.lv [ skatīts 10.05.2015.]. http://www.km.gov.lv/lv/ministrija/izcilibas_balva.html.

311. Balva: Kultūras mantojuma Lielā Gada balva. Pieškir kopš 2002. gada Valsts Kultūras pieminekḷu aizsardzības inspekcija [tiešsaiste]. mantojums.lv [skatīts 10.05.2015.]. https://mantojums.lv/lv/jaunumi/kulturas-mantojuma-gada-balva-2013-laureati/.

312. Balva: Latvijas Būvniecības gada balva. Piešksir kopš 2013. gada mediji Latvijas Arhitektūra un Latvijas Būvniecība [tiešsaiste]. latvijasbuvnieciba.lv [skatīts 10.05.2015.]. http://www.latvijasbuvnieciba.lv/LB/lb-gadabalva-2014/.

313. Balva: Latvijas Gada balva arhitektūrā. Piešķir kopš 1995. gada Latvijas Arhitektu savienība [tiešsaiste]. latarh.lv [skatīts 10.05.2015.]. https://www.latarh.lv/gadabalva/2015-gada-labakie/.

314. Balva: Latvijas regionālās arhitektūras balva. Pieškị kopš 2012. gada Rīgas Tehniskā Universitātes Arhitektūras un pilsētplānošanas fakultāte [tiešsaiste]. apf.rtu.lv [skatīts 10.05.2015.]. http://www.apf.rtu.lv/lv/node/426.

315. Balva: Mies van der Rohe prize. Piešķir kopš 1988. gada (Latvijā kopš 2005. gada) Eiropas Komisija [tiešsaiste]. miesarch.com [ skatīts 10.05.2015.]. https://www.miesarch.com/archive.

316. Balva: Rīgas arhitektūras Gada balva. Piešķir kopš 2011. gada Rīgas pilsētas arhitekta birojs [tiešsaiste]. Arhitekts.riga.lv [ skatīts 10.05.2015.].

http://www.arhitekts.riga.lv/index.php.

317. Balva: Starptautisko īpašumu balva. Piešķirta 2014. gadā [tiešsaiste]. International Property Media Ltd [skatīts 10.05.2015.]. http://propertyawards.net/europe-2014.

318. Balva: Ventspils pilsētas balva "Baltā Dūna”. Piešksir kopš 2001. gada Ventspils pašvaldība [tiešsaiste]. Ventspils.lv [ skatīts 10.05.2015.]. http://www.ventspils.lv/lat/pilseta/74054norisinasies-ikgadejais-arhitektu-lielais-ziemas-pasakums-balta-duna-2014. 
319. Basulto, D. Venice Biennale 2012: Elbphilharmonie/Herzog \& de Meuron [online]. Archdaily.com [cited 12.03.2016.]. http://www.archdaily.com/269531/venice-biennale2012-elbphilharmonie-herzog-de-meuron.

320. Britton, K. A Regionalist Panorama for Architecture and Beyond, Metropolitics [online]. Metropolitiques.com [cited 30.01.2013]. http://www.metropolitiques.eu/A-RegionalistPanorama-for.html.

321. Brokane, L. Publiskā apspriešana: realitāte vai fikcija [tiešsaiste]. LETA: Rīgas Balss, 14.08.2008. [skatīts 01.10.2016.]. www.leta.lv/arhivs.

322. Budže, K. 21. gadsimta vislaikmetīgākā arhitektūra ir pagātnes mantojums [tiešsaiste]. Arterriory.com [ citēts 15.12.2015.].

http://www.arterritory.com/lv/dzivesstils/arhitektura/3717:21._gadsimta_vislaikmetiga ka_arhitektura_ir_pagatnes_mantojums.

323. Butters, Ch. A Holistic Method of Evaluating Sustainability [online]. Norwegian Architects for Sustainable Development (NABU), 2012 [cited 15.12.2015].

http://www.universellutforming.miljo.no/file_upload/idebank\%20article $\% 20$ chris $\% 20 \mathrm{~b}$ utters.pdf.

324. Dambis, J. Kultūras pieminekḷu aizsardzības sistēma Latvijā [tiešsaiste]. Latvijas Arhitektu savienība, 09.03.2018. [skatīts 01.05.2018.]. skatīts https://pkpp.lv/course/10017-2/.

325. Diskusija : Kā vienkāršot būvniecības procesu - cel̦š, pa kuru jāiet [tiešsaiste]. Portals.lv [skatīts 01.03.2018.]. https://lvportals.lv/viedokli/292246-diskusija-ka-vienkarsotbuvniecibas-procesu-cels-pa-kuru-jaiet-2017.

326. Diskusija : Kur meklējama nacionālā identitāte arhitektūrā [tiešsaiste]. La. lv [skatīts 14.05.2013.] http://www.la.lv/kur-meklejama-nacionala-identitate arhitektura\%E2\%80\%A9-diskusija-2/.

327. Eksperta viedoklis: vai UNESCO Rīga sagrūs [tiešsaiste]. City24.lv [skatīts 04.05.2018.] https://www.city24.lv/lv/nekustama-ipasuma-zinas/10887/eksperta-viedoklis-vaiunesco-riga-sagrus.

328. European Institute for public participation : Public Participation in Europe. An international perspective, 2009 [online]. European Institute for public participation [cited 01.10.2016.]. http://www.partizipation.at/eipp_public_participation0.html.

329. Frearson, A. Elbphilharmonie by Herzog \& de Meuron at Venice Architecture Biennale 2012 [online]. Dezeen.com [cited 13.03.2016.].

http://www.dezeen.com/2012/08/30/elbphilharmonie-by-herzog-de-meuron-at-venicearchitecture-biennale-2012/.

330. Flyvbjerg, B. Phronetic Planning Research: Theoretical and Methodological Reflections [online]. Planning Theory and Practice, 2004 [cited 03.03.2017.]. https://ssrn.com. 
331. Goldstein, E.B. ed. Bayesian approach: Perception as Informational Extraction [online]. Encyclopedia of Perception, 201-5, Sage Publications, 2010. [cited 03.03.2016.]. http://sk.sagepub.com.

332. Groskaufmanis, M. Intervija, K. Kalns, Laikraksts Diena [tiešsaiste]. www.diena.lv [skatīts 24.11.2017.]. https://www.diena.lv/raksts/kd/intervijas/intervija-ar-arhitektu-matisugroskaufmani.

333. Heller, B. G. Red Business, Blue Business [online]. www.di.net [cited 03.03.2017.]. https://www.di.net/articles/red_business_blue_business/.

334. Hamurapi likumu kodekss : Ārvalstu tiesību avoti (no vissenākajiem laikiem līdz 1689. gadam) [tiešsaiste]. Vesture.eu [skatīts 03.03.2018.].

http://vesture.eu/index.php/Hamurapi_likumi .

335. Hofmann, S. Architecture Is Participation : Die Baapiloten : Methods and Projects [online]. DieBaupiloten, 2015. [cited 02.04.2016]. http://www.baupiloten.com/2016/03/04/architecture-is-participation/.

336. Inglehrats, R., Wezels, Ch. World Value Survey Map, 2006 [online]. Worldvaluesurvey.org [cited 04.03.2015.]. http://www.worldvaluessurvey.org/images/Cultural_map_WVS6_2015.jpg.

337. Kalkatechi, M. Nonmodern regionalism and sustainability: the case of two contexts [online]. College of Architecture and Environmental Design of Kent State University, August 2009. [cited 10.02.2013.]. https://etd.ohiolink.edu/rws_etd/document/get/kent1248015232/inline.

338. Konference: Kultūras mantojuma, mūsdienu arhitektūras un dizaina mijiedarbība [tiešsaiste]. Latvijas Prezidentūra Eiropas Savienības Padomē, Starptautiska konference, 2013.gada 12.-13.marts [skatīts 02.02.2016.]. https://mantojums.lv/media/uploads/dokumenti/konf_sem_diksusiju_dokumenti/konfer ences_delegatu_pazinojums_13032015_final_lv.pdf.

339. Kārkliṇa, K. Recenzija grāmatai "Mūsdienu kultūras stāvokḷi. Rīga” [tiešsaiste]. Megaphone Publishers, 2018 [skatīts 04.04.2018]. http://hilbig.lv/mp/rewiev-bykristiana-karklina-university-of-latvia-recenzija-gramatai-musdienu-kulturas-stavokliriga-2.

340. Kellow, P. Architecture and Ideology [online]. INTBAU, France, 2006 [cited 02.09.2016]. http://www.intbau.org/archive/essay15.htm.

341. Konference : Būvniecības kvalitāte Latvijā [tiešsaiste]. Rīgas Tehniskā universitāte (RTU), Ilgtspējìgas Būvniecības padome (IBP), 2014-2016 [skatīts 05.05.2016.]. http://kvalitatebuvnieciba.lv/prezentacijas/.

342. Krastiṇš, J. Arhitektūras stili Latvijā [tiešsaiste 02.02.2012.]. http://e.znet.lv/Arhitekt_stili_Latvija_Text.pdf.

343. Krastiňš, J. Reinholds Georgs Šmēlings (1840-1917). Rīgas pilsētas arhitekts [tiešsaiste 02.02.2012.]. http://e.znet.lv/Shmelings_lat.pdf. 
344. Kūle, M. Vai dzīvosim bez vērtībām. Pārdomas par humanitāro pētījumu lomu nacionālās identitātes veidošanā [tiešsaiste]. Lvportals.lv [skatīts 01.07.2010.].

https://lvportals.lv/viedokli/194196-vai-dzivosim-bez-vertibampardomas-parhumanitaro-petijumu-lomu-nacionalas-identitates-veidosana-2009.

345. Law, J. Objects, spaces and Others [online]. Lancaster: Lancaster University, The Centre of Science Studies, 2000 [cited 02.11.2016.]. http://www.comp.lancs.ac.uk/sociology/papers/Law-Objects-Spaces-Others.pdf.

346. Latvijas Arhitektu Savienība : Latvijas Arhitektu savienības struktūra [tiešsaiste]. Latarh.lv [skatīts 20.04.2012.]. https://www.latarh.lv/las/parvaldes-struktura/.

347. Latvijas Arhitektu savienība : Arhitektūras nedēl̦a 2018 [tiešsaiste]. Latarh.lv [skatīts 20.05.2018.]. https://www.latarh.lv/ar-pasakumu-programmu-tiks-atzimetaarhitekturas-nedela/.

348. Latvijas kultūras kanons [tiešsaiste]. Kultūraskanons.lv [skatīts 12.10.2012.]. https://kulturaskanons.lv/archive/vecrigas-siluets/.

349. Lasmane, S. Kāda ir mediju vara Latvijā [tiešsaiste]. Delfi.lv [skatīts 08.08.2015.]. http://www.delfi.lv/news/national/politics/skaidrite-lasmane-kada-ir-mediju-varalatvija.d?id=18856346.

350. Leitāne, L. Architectural competitions 2004-2013 : 100 addresses the Historic centre of Riga, 2015 [online]. Academia.edu [cited 12.10.2015.]. https://www.academia.edu/29514040.

351. Leitāne, L. Arhitektūras konkursu prakse Rīgā : 1991-2013 [tiešsaiste]. Arhitekts.riga.lv [skatīts 12.10.2015.] http://ej.uz/rigaskonkursi_petijums.

352. Lejnieks, J., Meiers, G., Kukainis, I. Rīgas panorāma un siluets kā Eiropas mantojuma zīmes vieta [online]. Valsts Kultūras Piemineklu Aizsardzības Inspekcija, 2015 [skatīts 08.08.2017.]. https://mantojums.lv/lv/.

353. Lin, J., Mele, C. ed. The Urban Sociology Reader [online]. 2nd ed. The Routledge, 2012 [cited 12.10.2015.]. https://www.taylorfrancis.com/books/e/9780203103333.

354. Mace, A. Suburbanization [online]. in: Kitchin, $R$. and Thrift, $N$. (ed.) International Encyclopedia of Human Geography. Oxford: Elsevier, 2009. pp. 77-81 [cited 12.10.2015.]. https://westminsterresearch.westminster.ac.uk/item/90y50/suburbanization.

355. MacLeod, G., Ward, K. Encyclopedia of Urban Studies: Patchwork Urbanism [online]. SAGE Knowledge, 2009. [cited 12.10.2015.]. http://sk.sagepub.com/reference/urbanstudies/n211.xml.

356. Makau, J. M. Encyclopedia of Identity: Diversity [online]. SAGE knowledge, 2010. [cited 12.10.2015.]. https://sk.sagepub.com/reference/identity. 
357. McGuirk, P., Dowling, R. Neoliberal privatisation : Remapping the public and the private in Sydney's masterplanned residential estates [online]. Political Geography, 2009 [cited 12.10.2015.]. https://researchers.mq.edu.au/en/publications/neoliberal-privatisationremapping-the-public-and-the-private-in-.

358. Mediju portāls: Diskusija : Par sakārtotu un laikmetīgu vidi Ikšksilē [tiešsaiste]. A4d.lv, 2008 [citēts 01.10.2016.]. http://www.a4d.lv/lv/notikumi/1220.

359. Mediju portāls: Ikšksiles novada kultūras centrs [tiešsaiste]. $a 4 d . l v, 2008$. [skatīts 01.10.2016.]. http://www.a4d.lv/lv/projekti/ikskiles_novada_kulturas_centrs/.

360. Mediju portāls: “Grēcinieku 25" sāga [tiešsaiste]. Arterritory.com, 2014 [skatīts 01.10.2016.]. http://www.arterritory.com/lv/teksti/raksti/4141-grecinieku_25_saga.

361. Mediju portāls: Apstrīd 20,5 miljonu vērta muzeju krātuvju kompleksa būvniecības iepirkuma rezultātus [tiešsaiste]. Dienas bizness, 2016. [skatīts 01.10.2016.]. http://www.db.lv/ipasums/apstrid-20-5-miljonu-verta-muzeju-kratuvju-kompleksabuvniecibas-iepirkuma-rezultatus- 444313 .

362. Mediju portāls: Sākušies rakstniecības un mūzikas muzeja rekonstrukcijas darbi [tiešsaiste]. Delfi, 2016 [skatīts 01.10.2016.]. http://www.delfi.lv/kultura/news/culturenvironment/sakusies-rakstniecibas-unmuzikas-muzeja-rekonstrukcijas-darbi.d?id=47543791.

363. Mediju portāls: Sākta sabiedrību satraukušās viesnīcas 'Hilton' būvniecība [tiešsaiste]. Delfi.lv, 2017 [skatìts 01.10.2017.]. http://m.delfi.lv/bizness/article.php?id=48634419.

364. Mediju portāls: Gaismas pils izmaksas vairāk nekā desmit gados - 268 miljoni eiro [tiešsaiste]. Lsm.lv, 2014. [skatīts 01.10.2017.].

http://www.lsm.lv/lv/raksts/latvija/zinas/grafiks-gaismas-pils-izmaksas-vairak-nekadesmit-gados-268-miljo.a88285/.

365. Mediju portāls: Rīgas arhitekts : Okupācijas muzeja piebūve nekad nav apspriesta ar sabiedrību [tiešsaiste]. Nra.lv [skatīts 01.10.2017.]. http://nra.lv/latvija/riga/163527rigas-arhitekts-okupacijas-muzeja-piebuve-nekad-nav-apspriesta-ar-sabiedribu.htm.

366. Mediju portāls: Rēzeknes koncertzāles celtniecībā nodarbināti nelegāli strādnieki [tiešsaiste]. Pietiek.com, 2012 [skatīts 01.10.2017.].

http://www.pietiek.com/raksti/rezeknes_koncertzales_celtnieciba_nodarbinati_nelegali_st radnieki.

367. Mediju portāls: Melbārde: Ieilgušas iepirkuma procedūras dēḷ Rīgas pils 2018. gadā netiks atvērta [tiešsaiste]. TVNET, 2018 [skatīts 01.10.2018.].

http://www.tvnet.lv/zinas/latvija/631893-

melbarde_ieilgusas_iepirkuma_proceduras_del_rigas_pils_2018gada_netiks_atverta.

368. Mickos, M. An architecture of participation [online]. Opensource.com, 2012 [cited 01.10.2016.]. https://opensource.com/business/12/6/architecture-participation.

369. Murphy, M., E. World Population: Toward the Next Century [online]. Washington, DC, Population Reference Bureau, 1994. [cited 15.02.2017.]. http://reports.weforum.org. 
370. Nekustamā īpašuma tirgus attīstības procesi un to ietekme uz Rīgas teritoriālo attīstību [tiešsaiste]. Nira fonds, Rïgas domes Pilsētas attīstības departaments, 2004 [skatīts 01.10.2014.]. http://www.sus.lv/lv/petijumi/nekustama-ipasuma-tirgus-attistibasprocesi-un-ietekme-uz-rigas-teritorialo-attistibu.

371. OECD Better Life Initiative: Measuring Well-Being and Progress [online]. Organisation for Economic Co-operation and Development (OECD) [cited 15.02.2017.]. https://www.oecd.org/statistics/better-life-initiative.htm.

372. Par ilgtspējīgu būvniecību Latvijā. Ilgtspējīgas Būvniecības padome [tiešsaiste 18.05.2012.]. http://www.ibp.lv/lv/par-projektu/par-ilgspejigu-buvniecibu.

373. Politikas veidošanas rokasgrāmata. Pārresoru koordinācijas centrs, 2016 [tiešsaiste, 01.01.2019]. https://www.pkc.gov.lv/sites/default/files/imageslegacy/pkc_rokasgramata_090316_web.pdf.

374. Peck, J., Tickell, A. Neoliberalizing Space [online]. Wiley, 2002, Antipode 34: 380-404. [cited 15.02.2014.]. https://onlinelibrary.wiley.com/doi/abs/10.1111/1467-8330.00247.

375. Pelcmane, S., Ulberts, V. Sabiedriskās apspriešanas - nopietni vai ķeksī̌sa pēc [tiešsaiste]. TVNET, 2005 [skatīts 01.10.2016.]. http://www.tvnet.lv/zinas/viedokli/293155sabiedriskas_apspriesanas_nopietni_vai_keksisa_pec.

376. Raskin, P. The great Transition: The Promise and Lure of Times Ahead [online]. Boston, MA: Stockholm Environment Institute, 2002. [cited 15.02. 2017.]. https://www.researchgate.net/publication/273698260_The_Great_Transition_The_Promis e_and_Lure_of_Times_Ahead.

377. Rīgas pilsētas ainavu teritoriju izdalīšana, analīze un novērtēšana. Latvijas Universitāte, Geogrāfijas un Zemes zinātṇu fakultāte, 2019 [tiešsaiste 01.10.2016.]. http://www.sus.lv/files/ainava_atskaite_kopaa.pdf.

378. Sarma, V. Būvniecība Latvijā [tiešsaiste]. Biedrības Latvijas Būvuznēmēju partnerība [skatīts 12.04.2017.]. http://www.latvijasbuvnieki.lv/nozares-dati/petijumi/.

379. Social Progress Imperative [online]. Social Progress Imperative [cited 15.02.2017.]. https://www.socialprogress.org.

380. Statistika par piešķirtajiem Latvijas valsts apbalvojumiem [tiešsaiste]. President.lv [skatīts 05.05.2015.]. https://www.president.lv/lv/valsts-apbalvojumi/apbalvotie-un-statistika.

381. Taurens, J. Jebkurā literatūrā, mākslā un laikmetā var atrast kaut ko nozīmīgu [tiešsaiste 20.04.2018.]. https://www.diena.lv/raksts/kd/intervijas/janis-taurens-jebkuraliteratura-maksla-un-laikmeta-var-atrast-kaut-ko-nozimigu-14073825.

382. Taurens, J. Mana pieredze doktorantūrā [tiešsaiste 20.04.2018.]. http://ljza.lv/wpcontent/uploads/2012/03/Mana-pieredze-doktorantuuraa_Janis-Taurens.pdf.

383. European Environment Agency : Urban sprawl in Europe: The ignored challenge [online]. EEA Report, No.10/2006. [cited 15.02.2017.]. https://www.eea.europa.eu/publications/eea_report_2006_10. 
384. Valsts Mākslas muzejs : Mākslas muzeja rekonstrukcija ieilgs par gadu, izmaksas neprognozē [tiešsaiste 12.04.2016.].

http://www.tvnet.lv/zinas/latvija/497299makslas_muzeja_rekonstrukcija_ieilgs_par_gadu _izmaksas_neprognoze.

385. Veinberga, S. Komunikācijas traucējumi un to neprognozējamās sekas [tiešsaiste 12.04.2016.]. https://sandraveinberga.com/publicistika/komunikacijas-traucejumi-un-toneprognozejamas-sekas/.

386. Vīnbergs, V. Pārsteigums Talsos. Pārpubl. no Latvijas Arhitektūras Burtnīca Nr. 86 [tiešsaiste 12.04.2016.]. http://abc.lv/?id=eku_veidi\&template=abc_raksts\&article=parsteigums_talsos.

387.Vīnbergs, V. Balvas faktors. Satori.lv [tiešsaiste 12.04.2016.]. http://www.satori.lv/article/balvas-faktors.

388. Vīnbergs, V. Traǵēdija un tās arhitekti. Rigaslaiks.lv [tiešsaiste 12.04.2016.]. https://www.rigaslaiks.lv/zurnals/komentari/tragedija-un-tas-arhitekti-19221.

389. VKPAI portāls: Par lielveikala "Depo" būvniecību Jelgavā [tiešsaiste 15.04.2016.]. http://mantojums.lv/lv/jaunumi/par-lielveikala-depo-buvniecibu-jelgava/.

390. Zinuu aǵentūra: Monitoring and publicity analysis [tiešsaiste]. LETA, 2016 [Skatīts 10.02.10.03.2016.].

391. Zvirgzdiṇš, A. Kas ir laba arhitektūra. Pārpubl. no Latvijas Arhitektūras Burtnīca Nr. 86 [tiešsaiste 19.06.2007.]. https://abc.lv/raksts/kas_ir_laba_arhitektura.

392. Zvirgzdiṇš, A. Arhitektūra kā māksla II [tiešsaiste 01.01.2017.]. http://www.a4d.lv/lv/raksti/arhitektura_ka_maksla_ii/.

\section{Legislative enactments and other documents}

393. Administratīvā procesa likums: LR likums, Saeimā pieṇemts 2001. gada 25.oktobrī. Likumi.lv [tiešsaiste 15.10.2014.]. http://www.likumi.lv/doc.php?id=55567.

394. Arhitektūras nozares stratēǵija 2015-2020. LR Kultūras ministrija [tiešsaiste 15.10.2014.].

https://www.km.gov.lv/uploads/ckeditor/files/Strategija_arhitektura_final.pdf

395. Arhitektūras politikas pamatnostādnes 2009.-2015. gadam. Politikas plānošanas dokumentu datubāze [tiešsaiste 30.10.2017.]. http://polsis.mk.gov.lv/view.do?id=3102.

396. Attīstības plānošanas sistēmas likums: LR likums, Saeimā pieṇemts 2008. gada 8.maijā. Likumi.lv [tiešsaiste 15.10.2017.]. http://www.likumi.lv/doc.php?id=175748.

397. Arhitektu savienības nolikums par projektu konkursiem. Latvijas Arhitektu savienība [tiešsaiste 15.10.2017.]. https://www.sif.gov.lv/nodevumi/nodevumi/3284/nolikums\%20par\%20projektu\%20ko nkursiem.pdf. 
398. Būvniecības ieceres publiska apspriešana. Rìgas Domes portāls [tiešsaiste 15.10.2017.]. https://www.eriga.lv.

399. Būvniecības likums: LR likums, Saeimā pien,emts 2013. gada 7.septembrī Likumi.lv [tiešsaiste 30.10.2010.]. https://likumi.lv/doc.php?id=258572.

400. Continuing Professional Development [online]. Architect's Council of Europe (ACE) [cited 15.07.2017.]. https://www.ace-cae.eu/access-to-the-profession/continuing-professionaldevelopment/.

401. Davosas deklarācija. Mantojums.lv, 2018 [tiešsaiste15.02.2018.].

http://mantojums.lv/lv/jaunumi/-davosas-deklaracija-Baukultur/.

402. Eiropas Padomes vispārējā konvencija par kultūras mantojuma vērtību sabiedrībai: LR likums, Saeimā pieṇemts 2006. gada 2. martā. Likumi.lv [tiešsaiste 15.10.2017.]. https://likumi.lv/doc.php?id=130436\%20.

403. European Landscape Convention: Identity [online]. Europen Council Florence, 20.10.2000. [cited 15.10.2015.]. http://www.coe.int/t/dg4/cultureheritage/heritage/Landscape/.

404. European Forum for Architectural Policies: Survey on Architectural Policies in Europe [online]. European Forum for Architectural Policies (EFAP), July 2012 [cited 14.06.2011]. http://www.efap-fepa.org/docs/EFAP_Survey_Book_2012.pdf.

405. Gavena, I., Jekale, I.,Valdmane, I., u.c. Metodiskais materiāls pašvaldības, iedzīvotāju un uzṇēmēju interešu saskaṇošana - sabiedriskā apspriešana kā instruments [tiešsaiste]. Kurzemesregions.lv [skatīts 15.10.2017.]. https://www.kurzemesregions.lv/sabiedriskasapspriesanas-organizesanas-un-sabiedribas-iesaistes-ieteikumi/.

406. Introduction to the master document for an architectural design competition by the ACE online]. Architect's Council of Europe (ACE) [cited 02.01.2016]. http://www.acecae.eu/uploads/tx_jidocumentsview/ADCMasterDoc.pdf.

407. Kārkliṇš, K. Rīga World Heritage site impact evaluation method [online]. Rìga RD Pilsētas attistības departaments, 2013.[cited 15.12.2016.] http://www.kristskarklins.com/rvc.html.

408. Kārtība, kādā dibināmi valsts institūciju un pašvaldību apbalvojumi. MK noteikumi Nr. 928, 05.10.2010. Likumi.lv [tiešsaiste 15.12.2015.]. https://likumi.lv/doc.php?id=219237.

409. Kultūras mantojuma publiskā administrēšana. Valsts kultūras pieminekḷ a aizsardzības inspekcija [tiešsaiste 15.12.2015.].

http://www.mantojums.lv/?cat=654\&lang=lv\&fulltext_id=1423.

410. Kultūrpolitikas pamatnostādnes 2014.-2020. gadam "Radošā Latvija" (informatīvā daḷa) [tiešsaiste]. LR Kultūras ministrija, MK rīkojums Nr. 401, 2014.gada 29.jülijs [tiešsaiste 15.10.2017.].

https://www.km.gov.lv/uploads/ckeditor/files/KM_dokumenti/Radosa_Latvija.pdf.

411. Latvijas arhitektu aptauja. Latvijas arhitektu savienība, 2013 [tiešsaiste 15.10.2017.]. http://www.latarh.lv/arhivs. 
412. Latvijas Arhitektu savienība: Labas prakses nolikums. Rekomendācijas. Latvijas Arhitektu savienība, 2010 [tiešsaiste 02.01.2016.]. http://www.latarh.lv/f/faili/

Konkursu\%20labas\%20prakses\%20nolikums.pdf.

413. Latvijas Arhitektu savienība: Sertificēti arhitekti Latvijā. Latvijas Arhitektu savienība [tiešsaiste 20.04.2015.]. www.latarh.lv/par_mums; http://www.latarh.lv/certified.

414. Latvijas Būvniecības Padomes pilnvaras. Būvniecības likums, 8. pants [tiešsaiste 20.04.2015.]. http://likumi.lv/doc.php?id=258572.

415. Latvijas radošo savienību padome: Radošās savienības. LRSP [tiešsaiste 20.04.2015.]. http://design.lv/lv/partner/latvijas-radoso-savienibu-padome.

416. Latvijas Republikas Satversme: LR likums, Saeimā pieṇemts 1922. gada 15.februārī. Likumi.lv [tiešsaiste 15.10.2014.]. https://likumi.lv/doc.php?id=57980.

417.Leipcigas harta par ilgtspējīgām Eiropas pilsētām. Valsts valodas centrs [tiešsaiste 15.10.2010.].

http://www.vvc.gov.lv/export/sites/default/docs/STA/Tulkojumi_no_anglju_val/Dazhaad i/Leipzig_Charter_of_Informal_meeting_in_Terrirorial_Cohesion.doc.

418. Likums: Par pašvaldībām: LR likums, Saeimā pieñemts 1994. gada 19.maijā. Likumi.lv [tiešsaiste 20.04.2016.]. http://www.likumi.lv/doc.php?id=57255.

419. Likums: Par Eiropas ainavu konvenciju: LR likums, Saeimā pieṇemts 2007. gada 29.martā. Likumi.lv [tiešsaiste 14.10.2017.]. http://www.likumi.lv/doc.php?id=156001.

420. LR VARAM: Ainavu politikas pamatnostādnes 2013.-2019. gadam. Vides aizsardzības un reǵionālās attīstības ministrija [tiešsaiste 14.08.2016.]. http://www.VARAMpamn_21062013_ain.

421. Mārupes Būvvaldes dati: Detālplānojumi 2013. Marupe.lv [tiešsaiste 14.08.2014.]. http://www.marupe.lv/wpcontent/uploads/2013/07/Detalplanojumi-Nr.pdf.

422. Mārupes novada attīstības programma 2013.-2019. gadam. Marupe.lv [tiešsaiste 14.09.2014.]. http://www.marupe.lv/Marupes-novada-attistibas programma-2013_2019gadam.pdf.

423. Mārupes novada ilgtspējīgas attīstības stratēgija 2013.-2026. Marupe.lv [tiešsaiste 14.09.2014.]. http://www.marupe.lv/wp-content/uploads/2013/05/Marupes-novadailgtspejigas-attistibas-strategija-2013_2026-gadam.pdf.

424. Mārupes novada teritorijas plānojums 2014.-2026. gadam. Marupe.lv [tiešsaiste 14.09.2014.]. http://www.marupe.lv/speka-stajies-marupes-novada-teritorijas-planojums2014-2016-gadam/.

425. MK noteikumi Nr. 628: Noteikumi par pašvaldību teritorijas attīstības plānošanas dokumentiem. Likumi.lv [tiešsaiste 14.09.2014.]. http://likumi.lv/doc.php?id=269842. 
426. MK noteikumi Nr. 671: Būvniecības ieceres publiskas apspriešanas kārtība. Likumi.lv [tiešsaiste 01.10.2016.]. http://likumi.lv/ta/id/269978-buvniecibas-ieceres-publiskasapspriesanas-kartiba.

427. MK noteikumi Nr. 970: Sabiedrības līdzdalības kārtība attīstības plānošanas procesā. Likumi.lv [tiešsaiste 01.10.2016.]. http://likumi.lv/doc.php?id=197033.

428. MK noteikumu Nr. 311: Noteikumi par Latvijas būvnormatīvu LBN 208-15 Publiskas būves 2.4. punkts. Likumi.lv [tiešsaiste 15.04.2016.]. https://likumi.lv/ta/id/274995noteikumi-par-latvijas-buvnormativu-lbn-208-15-publiskas-buves.

429. MK noteikumu Nr. 500: Vispārīgie būvnoteikumi, 1. pielikums. Likumi.lv [tiešsaiste 15.04.2016.]. https://likumi.lv/doc.php?id=269069.

430. MK noteikumi Nr. 928: Kārtība, kādā dibināmi valsts institūciju un pašvaldību apbalvojumi. Likumi.lv [tiešsaiste 15.04.2016.]. https://likumi.lv/doc.php?id=219237.

431. Nacionālais attīstības plāns 2014. - 2020.gadam. NAP. lv [tiešsaiste 15.04.2016.] http://www.nap.lv/upload/cilveks_sabiedriba_valsts_2030.pdf.

432. Nacionālās arhitektūras padomes nolikums. LR Kultūras ministrija [tiešsaiste 01.10.2016.] https://www.km.gov.lv/lv/kultura/arhitektura/padome.

433. Noteikumi par kultūras pieminekḷu uzskaiti, aizsardzību, izmantošanu, restaurāciju un vidi degradējoša objekta statusa piešķiršanu. Likumi.lv [tiešsaiste 15.04.2016.]. https://likumi.lv/doc.php?id=78458.

434. Pasaules mantojuma vietas retrospektīvais īpašas nozīmes un universālās vērtības pamatojums. Rīgas vēsturiskais centrs. Latvija [tiešsaiste]. Valsts Kultūras Pieminekḷu Aizsardzības Inspekcija, 1997 [skatīts 15.04.2016.]. http://www.mantojums.lv/_rict_text/ docs/Riga_OUV_LV_final.pdf.

435. Pašvaldības pakalpojumu portāls: Būvniecības ieceres publiska apspriešana: Pakalpojuma kategoriju izklāsts [tiešsaiste 17.08.2016.]. https://www.eriga.lv.

436. Pašvaldības pakalpojumu portāls: Būvniecības ieceres publiska apspriešana: Normatīvie akti, kas reglamentē pakalpojuma sniegšanu [tiešsaiste 12.01.2017.].

437. Pieminekḷu saraksts. Valsts kultūras pieminekḷ aizsardzības inspekcija, IS. Mantojums.lv [tiešsaiste 15.11.2017.]. http://mantojums.lv/lv/piemineklu-saraksts/.

438. Policy statements in support of ACE manifesto [online]. Architect's Council of Europe (ACE) [cited 02.01.2016]. https://www.ace-cae.eu/policies/.

439. Rīgas Domes Īpašuma departamenta dati. Rïgas domes İpašuma departaments [tiešsaiste 10.03.2018.]. http://rdid.lv/.

440. Rīgas Domes Pilsētas attīstības komiteja. Rīgas pašvaldības portāls [tiešsaiste 15.04.2016.]. https://pasvaldiba.riga.lv/LV/Channels/Riga_Municipality/Riga_City_Council/Committees/ PilsetasAttKomiteja.htm. 
441. Rīgas Harta par autentiskumu un vēsturisko objektu atjaunošanu kultūras mantojuma kontekstā. Unesco.lv [tiešsaiste 10.03.2016.]. http://www.unesco.lv/lv/jaunumi/majaslapa-pieejama-rigas-harta/.

442. Rīgas ilgtspējīgas attīstības stratēǵija līdz 2030. gadam. Rīgas domes Īpašuma departaments [tiešsaiste 15.04.2016.]. http://www.rdpad.lv/wpcontent/uploads/2014/11/LV_STRATEGIJA.pdf.

443. Rīgas Plānošanas Reǵiona ilgtspējīgas attīstības stratēgiijas 2014-2030 un attīstības programmas 2014-2020 izstrādes pārskats. Rīgas plānošanas reǵions [tiešsaiste 15.04.2016.]. http://www.rpr.gov.lv/uploads/.

444. Rīgas vēsturiskā centra saglabāšanas un aizsardzības likums. www.likumi.lv [tiešsaiste 30.10.2010.]. http://www.likumi.lv/doc.php?id=76001s.

445. Rīgas pilsētas arhitekta birojs. Arhitekts.riga.lv [tiešsaiste 15.04.2016.]. http://www.arhitekts.riga.lv/index.php?option=com_content\&view=article\&id=674\&Itemi $\mathrm{d}=401$.

446. Saeima: Rīgas vēsturiskā centra saglabāšanas un aizsardzības likums, 1. panta 3. punkts "kultūrvēsturiskas vides pārveidošana". LR likums, Saeimā pieṇemts 2003. gada 29. maijā. [tiešsaiste 15.12.2015.]. https://likumi.lv/doc.php?id=76001\&version_date=14.06.2005.

447. Saeima: Publisko iepirkumu likums. 2.pants: Likuma mērksis. LR likums, Saeimā pieṇemts 2016. gada 15.decembrī. Likumi.lv [tiešsaiste 01.10.2016.]. https://likumi.lv/doc.php?id=287760.

448. Saeima: Latvijas Nacionālās bibliotēkas projekta īstenošanas likums. LR likums, Saeimā piennemts 2003. gada 8. maijā. Likumi.lv [tiešsaiste 01.10.2016.]. https://likumi.lv/doc.php?id=75138.

449. Saeima: Latvijas Okupācijas muzeja likums. LR likums, Saeimā pieṇemts 2006. gada 5. oktobrī. Likumi.lv [tiešsaiste 01.10.2016.]. https://likumi.lv/doc.php?id=146475.

450. Saeima: Publisko iepirkumu likums. 8. pants: Iepirkuma procedūru veidi un to piemērošana. LR likums, Saeimā pieṇemts 2016. gada 15. decembrī. Likumi.lv [tiešsaiste 01.10.2016.]. https://likumi.lv/doc.php?id=287760.

451. Saeima: Rīgas vēsturiskā centra saglabāšanas un aizsardzības likums. 5.panta 5.punkts. LR likums, Saeimā pieṇemts 2003. gada 29. maijā. Likumi.lv [tiešsaiste 01.10.2016.]. https://likumi.lv/doc.php?id=76001.

452. Salmon, L. UNESCO World Heritage List [online]. World Heritage List [cited 12.12.2015.]. http://www.thesalmons.org/lynn/world.heritage.html.

453. Šteinerts, A. Latvijas Būvnormatīvu sistēmas attīstības koncepcija līdz 2020. Būvniecības valsts kontroles birojs (BVKB) [tiešsaiste 01.10.2017.]. http://bvkb.gov.lv/sites/default/files/buvnormativu_koncepcijas_projekts_i_versija_astei nerts.pdf. 
454. Teritorijas attīstības plānošanas likums. LR likums, Saeimā pieṇemts 2011. gada 13. oktobrī. Likumi.lv [tiešsaiste 01.10.2016.]. https://likumi.lv/ta/id/238807-teritorijasattistibas-planosanas-likums.

455. Teritorijas izmantošanas un apbūves noteikumi: Rīgas Vēsturiskā centra un tā aizsardzības zonas teritorijas plānojums (RVZ AZ TIAN). Rīgas domes pilsētas attīstības departaments [tiešsaiste 01.10.2016.]. http://www.rdpad.lv/rtp/rvc/.

456. Teritorijas plānošanas likums. LR likums, Saeimā pieṇemts 2002. gada 22. maijā. Likumi.lv [tiešsaiste 14.10.2015.]. https://www.vestnesis.lv/ta/id/63109-teritorijasplanosanas-likums.

457. UNESCO OECD Economic Surveys: Latvia [online]. Oecd-iLibrary.org [cited 12.02.2015.]. https://www.oecd-ilibrary.org/economics/oecd-economic-surveys-latvia2015_9789264228467-en.

458. UNESCO: Standard regulations for international competitions in architecture and town planning UIA, 1978 [online]. Competition Guide [cited 02.01.2015.].

http://portal.unesco.org/en.

459. UNESCO: Vispārējā kultūras daudzveidības deklarācija [tiešsaiste]. UNESCO Latvijas Nacionālà komisija, 2002 [citēts 15.10.2017.].

http://www.unesco.lv/lat/index/documents/declarations.html.

460. UNESCO: Recommendation on the Historic Urban Landscape/Environment [online]. Unesco.org, 2011 [cited 15.12.2015.]. http://whc.unesco.org/en/syndication.

461. Valsts apbalvojumu likums. LR likums, Saeimā pieṇemts 2004. gada 4. martā. Likumi.lv [tiešsaiste 15.10.2014.]. https://likumi.lv/doc.php?id=85981.

462. Valsts Kultūras pieminekḷu aizsardzības inspekcija: Par inspekciju [tiešsaiste 15.12.2015.]. http://mantojums.lv/lv/par-inspekciju/.

463. The Venice charter 1964: International charter for the conservation and restoration of monuments and sites [online]. International Coulncil on Monuments and Sites [cited 27.12.2013.]. https://www.icomos.org/charters/venice_e.pdf.

464. Vietējās pašvaldības teritorijas plānošanas noteikumi. MK Not. Nr. 1148, 2009. Likumi.lv [tiešsaiste 30.10.2010.]. http://www.likumi.lv/doc.php?id=198901.

465. World Heritage Commitee, List Nr. 852 [online]. Unesco.lv, 1997 [cited 15.12.2015.]. http://www.unesco.lv/lv/unesco-latvija/unesco-latvija-1/.

466. Zemgales plānošanas regiions. Sabiedriskās apspriešanas organizēšanas un sabiedrības iesaistes ieteikumi, 2011 [tiešsaiste]. www.kurzemesregions.lv [skatīts 01.10.2016.]. http://www.kurzemesregions.lv/jomas/Teritorijas_attistibas_planosana/KPR_teritorijas_ planojums/Teritorijas_attistibas_planosana/Metodiskie_ieteikumi_sabiedrisko_apspriesa nu_organizesanai_un_sabiedribas_iesaistei. 


\section{Figures}

467. Jencks, C. 2000 July: Jencks' Theory of Evolution, an Overview of 20th Century Architecture [online]. The Architectural Review; 7 December 2011 [cited 10.10.2014.]. http://www.architectural-review.com/2000-july-jencks-theory-ofevolution-an-overviewof-20th-century-architecture/8623596.article.

468. Meyer, A., Kuhlbrodt, S., Aerberhard, B. ETH Zurich lecture course. Architecture - a Synoptic vision=Example of an evolutionary history, a prospectus of developments from 1900 to today. Berlin: Birkhauser Verlag AG, 2008. 22 p. ISBN 9783764388768. 